\title{
A Preference for Liberty: The Case Against Involuntary Commitment of the Mentally Disordered
}

\author{
Stephen J. Morse $†$
}

In the last two decades there have been changes of immense magnitude in the laws pertaining to involuntary commitment of mental patients to hospitals. ${ }^{1}$ In 1960 , involuntary mental hospitalization and treatment were decisions almost entirely within the discretion of mental health professionals. Although, at least in theory, commitment had to be accomplished in conformity with statutory requirements, effective substantive and procedural restraints on families and mental health professionals who sought involuntary commitment were virtually nonexistent. Moreover, the degree of power and discretion vested in mental health professionals was not considered problematic-it seemed fittimg to allow niedical personnel to make what were viewed as essentially medical decisions.

In the mid-1960's, however, the picture changed radically. Lawyers interested in civil rights turned their attention to involuntary hospitalization at the same time that various conceptual and political critiques of psychiatry, especially imstitutional psychiatry, gathered ino-

$\dagger$ Professor of Law, University of Southern California Law Center, and Professor of Psychiatry and the Behavioral Sciences, University of Southern California School of Medicine. A.B. 1966, Tufts University; J.D. 1970, Ph.D. (Psychology and Social Relations) 1973, Harvard University.

This Article was presented at the Gith International Symposium on Law and Psychiatry held in Charlottesville, Virginia in June 1981, under the auspices of the Institute of Law, Psychiatry, and Public Policy of the University of Virginia School of Law and School of Medicine. In an earlier form, it was presented at the Biennial Convention of the Anierican Psychology-Law Society held at the University of Maryland School of Law in October 1979.

In modified form, this Article will appear as a chapter in C. WARREN, THE COURT OF LAST RESORT: MENTAL ILLNESS AND THE LAW, to be published in 1982 by the University of Chicago Press, and in my forthcoming book, THE JURISPRUDENCE of CRAZINESS, to be published by the Oxford University Press.

Paul Chodoff, Len Kaplan, John Monahan, David Rosenhan, Serena Stier, and David Weisstub are due grateful thanks for providing perceptive and helpful, if not always assenting, comments on earlier drafts. I should also like to thank my various research assistants, Joan Mussoff, Jan Harris, Peg Casey, and Maureen Lee, for their help.

1. Developments in the Law-Civil Commitment of the Mentally Ill, 87 HARv. L. Rev. 1190 (1974) [heremafter cited as Developments]. See generally D. WexLeR, Mental Health Law: MAJOR ISSUES 11-57 (1981). 
mentum. ${ }^{2}$ In addition, the theory of community mental health and the wide usage of psychotropic drugs appeared to render long term involuntary hospitalization less advised and less necessary.

The legal watersheds were California's Lanterman-Petris-Short Act (LPS) ${ }^{3}$ in 1967, and the 1973 Wisconsin federal district court decision, Lessard v. Schmidt, ${ }^{4}$ both of which limited the state's power to commit persons involuntarily. Following LPS, the majority of states legislatively reformed commitment laws; ${ }^{5}$ following Lessard, numerous cases found state commitment laws unconstitutional and applied strmgent substantive and procedural due process protections to the involuntary commitment process. ${ }^{6}$ Most recently, as courts have faced a new generation of issues concerning mental patients' rights, there has been an expansion of the right of imvoluntary patients to refuse treatment. ${ }^{7}$ The balance between individual liberty and autonorny on the one hand, and the state's paternahistic right to confine and treat persons involuntarily on the other, has clearly shifted to a preference for hberty.

The "legalization" of commitment has occasioned an enormous and all too often dismaymg debate. Exchanges have been marred by charges and countercharges that are overblown and unfair. ${ }^{9}$ Involuntary commitment and the actors in the system are portrayed in polar terms of good and evil. Proponents of legalization are accused of lackmg compassion or of not understanding clinical realities. Many mental liealth professionals are outraged by what they view as the legal system's wrongheaded interference with their ability to practice properly.

2. See, e.g., R. Laing, The Politics of Experience (1967); R.D. Laing \& Anti-PsychiATRY (R. Boyers \& R. Orrill eds. 1971); T. SZasz, LAw, Liberty and Psychlatry (1963); T. Szasz, The Myth of Mental Illness (rev. ed. 1974).

3. CAL. Welf. \& INST. Code $\$ \S 5000-5401$ (West 1972) (effective July 1, 1969).

4. 349 F. Supp. 1078 (E.D. Wis. 1972), vacated and remanded on procedural grounds, 414 U.S. 473 (1974), new judgment entered, 379 F. Supp. 1376, 1378 (E.D. Wis. 1974), vacated and remanded, 421 U.S. 957 (1975) (for reconsideration in light of Huffman v. Pursue, Ltd., 420 U.S. 592 (1975)), reaffd, 413 F. Supp. 1318 (E.D. Wis. 1976).

5. Schwitzgebel, Survey of State Commitment Statutes, in Civil CoMmitment AND SociaL Policy 47, 53 (A. McGarry et al. eds. 1981); e.g., MASs. Gen. LAws ANN. ch. 123, §§ 1-37 (West Supp. 1981); N.C. GeN. STAT. § 122-58.1-.28 (1979 Cum. Supp.).

6. E.g., Lynch v. Baxley, 386 F. Supp. 378 (M.D. Ala. 1974).

7. See Rogers v. Okin, 478 F. Supp. 1342 (D. Mass. 1979), modified, 634 F.2d 650 (1st Cir. 1980), cert. granted, 101 S. Ct. 1972 (1981); Rennie v. Klein, 462 F. Supp. 1131 (D.N.J. 1978), modiffed and remanded, 653 F.2d 836 (3d Cir. 1981). But see A.E. \& R.R. v. Mitchell, 5 MENTAL DiSAB. L. RPTR. 154 (D. Utah 1980).

8. This term is used to describe the increased involvement of the legal system through the imposition of substantive and procedural restraints. Simce the legal system's involvement in involuntary commitment has been almost uniformly for the purpose of restricting commitment and protecting patients' rights, "legalization," as used in this Article, more particularly describes the limitation of involuntary commitment through the imposition of legal restraints.

9. Rather than contribute to the overheated atmosphere by citing offenders, except when using direct quotations I shall assume that readers could easily call to mind specific examples of the phenomena I ain describing. 
They beheve that, on balance, patients have been harmed by legalization, and they have described the outcome as patients "dying with their rights on," 10 and having "the right to rot." 11 These professionals concede that there have been abuses in commitunent practices and hospital conditions in the past, but they believe that legalization is an unwise remedy and that it certainly has gone too far. Conversely, proponents of inedical authority are indicted for being unconcerned witl liberty and dignity and for acting in bad faith; well-ineaning inental health professionals are labeled jailers or worse.

To buttress their positions, advocates find or lypothesize apparently clear cases that seem to make difficult issues easily resolvable. While such cases arouse syinpathy or anger, they do not stimulate sensible discussion. It is relatively simple to find or construct "easy" cases, but doing so is an injustice to the enormous social, moral, and legal complexity of the question of involuntary hospitalization. Counparatively few actual cases are so extreine that most reasonable persons would agree that involuntary hospitalization was or was not warranted. ${ }^{12}$ Furthermore, society would not create a coinplex and expensive system of imvoluntary commitment to deal with the few cases of extreme craziness and disability that undeniably could warrant the need for involuntary lospitalization, nor would society abohish such a system to avoid a few clear cases of "railroading" normal persons into hospitals.

All those concerned with the involuntary commitment debate should recognize that niost proponents of commitment are not unconcerned with the liberty of those affected and that niost proponents of legalization or abohtion of commitunent are not lacking in compassion or concern for citizens who are disordered and apparently unable to cope successfully in our society. Name calling should cease. Moreover, advocates should no longer use unrepresentative cases to support their positions. Such evidence produces both poor social science and unsound bases for sensible social policy. What should be clear is that there is no ideal solution to the personal, family, and social problems associated with inental disorder. Maintaining, abolishing, or severely limiting involuntary commitunent all have costs and benefits for disordered persons and society at large. What is needed is reasonable and realistic analysis of the likely outcomes of various approaches.

10. Treffert, The Practical Limils of Patients' Rights, in PsYchiatrists and the Legal ProCESS: Diagnosis \& Debate 227, 227 (R. Bonnie ed. 1977).

11. Appelbaun \& Gutheil, The Boston State Hospital Case: 'Involuntary Mind Control'; the Constitution and the 'Right to Rot,' 137 AM. J. PsYCHIAT. 720, 723 (1980).

12. This is especially true, I believe, if the necessity for hospitalization is considered in a context where decent alternative treatment programs are available. 
The purpose of this Article is to offer a reasonable policy argument in favor of abolishing or severely limiting involuntary commitment of the mentally disordered. Constitutional arguments will not be presented. Although an argument that involuntary commitment is unconstitutional can be constructed, it would be unpersuasive and probably incorrect. The goal here is to persuade that involuntary commitment is a gravely unwise social institution, regardless of its constitutionality. ${ }^{13}$

It must be acknowledged at the outset that some clearly avoidable harm will come to individuals and to society if the positions taken in this Article are adopted as social policy. It inust also be acknowledged that a reasonable and coherent case can be made for maintaining involuntary commitment and for extending the authority of mental health professionals within the system. Nevertheless, this Article concludes that, on balance, our society, the mentally disordered, and even the mental health professions will be better off without involuntary coinmitment. At a time when inany argue that legalization has gone too far, this Article argues that it has not gone far enough.

To support these conclusions, Part I will consider the assumptions, evidence, and arguments concerning involuntary hospitalization. Following that, Part II will examine the paternalistic commitment reforms suggested by Alan Stone and Loren Rotl to see if they avoid the problems of the current system. Lastly, Part III will discuss the benefits that will follow from abolishing or severely limiting involuntary hospitalization. Although this Article hopes to persuade by this effort-or at least to help shift the burden of persuasion to the proponents of involuntary commitment-it will have achieved its primary purpose if it demonstrates that a reasonable and compassionate argument can be made for abolition of involuntary commitment and helps place the commitment debate on a more realistic and reasoned basis.

13. Because the basis of the argument is not grounded in constitutional law, it should be understood that the meanings of terms like "liberty" and "fundamental rights" as used in this Article are not coextensive with their meanings as declared by the Supreme Court.

Throughout most of the Article, discussion will focus on abolition in order to set forth the views most starkly. It should be understood, however, that the arguments may also be used to support extensive limitations on involuntary commitment.

On occasion, support for various propositions will refer to cases or other materials dealing with the mentally retarded. The arguments of this Article, however, apply only to the mentally disordered, and such support will be employed only where the situations of the mentally retarded and the mentally disordered are reasonably analogous.

Finally, the case presented applies only to adults. I believe the case against committing minors is even stronger, but the issues are sufficiently different to require separate consideration. 


\section{The Argument Against Involuntary Commitment}

Involuntary commitment is an extraordmary exercise of the pohice power and paternalism of the state. Although liberty is constantly infringed in various ways by state action-preventive detention through certain bail practices is but one example-the deprivation of liberty authorized by involuntary commitment laws is among the inost serious restrictions on individual freedom the state inay impose. Moreover, it may be imposed on the basis of predictions, without the prior occurrence of dangerous acts or other legally relevant behavior. Typically, the state inust have exceptionally weighty interests in order to justify such an exceptional deprivation of individual freedoin. It inust therefore be asked whether, in light of our national preference for liberty, a systein of involuntary commitment that is based on wide substantive standards and relatively lax procedures can be justified. It is argued in this Part that it cannot.

The objections to involuntary civil commitment are both theoretical and practical. First, it is difficult or impossible to support, with theory or data, the differential treatment of mentally disordered persons ${ }^{14}$ that allows them, but not normal persons, to be involuntarily committed. Second, the systein is unlikely to identify accurately those persons

14. It is impossible to provide a noncontroversial generic definition of mental disorder. The American Psychiatric Association admits as much in its currently operative and authoritative DIagnostic and Statistical Manual of Mental Disorders 5 (3d ed. 1980) [hereinafter cited as DSM-III], but then provides the following "conceptual" influences on the decision to categorize a "condition" as a mental disorder in DSM-IIl:

In DSM-III each of the mental disorders is conceptualized as a clinically significant behavioral or psychological syndrome or a pattern that occurs in an individual and that is typically associated with either a painful symptom (distress) or impairment in one or more important areas of functioning (disability). In addition, there is an inference that there is a behavioral, psychological, or biological dysfunction, and that the disturbance is not only in the relationship between the individual and society. (When the disturbance is limited to a conflict between an individual and society, this may represent social deviance, which may or inay not be commendable, but is not by itself a mental disorder.)

In DSM-III there is no assumption that each mental disorder is a discrete entity with sharp boundaries (discontinuity) between it and other mental disorders, as well as between it and No Mental Disorder.

Id. at 6.

I have argued previously that the categories of mental disorders all describe behavior that is considered crazy, meaning imexplicably irrational, weird, wild, nonsensical, or the like. The severity of mental disorder, according to this view, is simply a reflection of the degree of craziness exhibited by the actor. I prefer the term crazy because for legal purposes it is more descriptive and carries fewer connotations about disease processes that beg inportant questions about self-control. The full argument is presented in Morse, Crazy Behavior, Morals and Science: An Analysis of Mental Health Law, 51 S. CAL. L. Rev. 527, 543-60 (1978).

In this Article the terms mental disorder and craziness as described in this note will be used interchangeably. Of course, the Article is concerned primarily with those crazy persons who are lospitalized involuntarily, and it should be recognized that these persons are usually those considered severely crazy or mentally disordered. See note 55 infra. 
who should arguably be committed; consequently, large numbers of persons who are not properly committable will be unjustly and needlessly deprived of their liberty. Third, it is unlikely that the states will be able to provide the quality of care and treatment for those committed that is absolutely necessary to justify the enormous deprivation of hiberty caused by commitment. Finally, most, and probably all, of the alleged benefits of involuntary hospitalization can be provided by less intrusive alternatives that are equally efficacious but cause much less deprivation of hiberty.

\section{A. Mentally Disordered Persons Should Not Be Legally Distinguishable From Normal Persons}

The primary theoretical reason for allowing involuntary commitment of only the mentally disordered is the behef that their legally relevant behavior is the inexorable product of uncontrollable disorder, ${ }^{15}$ whereas the legally relevant behavior of normal persons is the product of free choice. It is believed, for example, that a normal person who experiences an impulse to commit a crime is capable of repenting or being deterred by the sanctions of the criminal law, ${ }^{16}$ and hence, may choose not to commit the crime. Thus, to preserve the person's autonomy and digmity, a normal person cannot be incarcerated until he or she actually offends the criminal law, even if the person's future dangerousness is highly predictable. ${ }^{17}$ On the other hand, the disordered person is thought to lack understanding or behavioral control, and therefore cannot change his or her mind or be deterred. ${ }^{18}$ Because the individual will ultimately have little or no choice in deciding whether to act violently, it does not violate the disordered person's dignity or autonomy to hospitalize him or her preventively, even in the absence of strong predictive evidence of future dangerousness.

The belief that disordered persons particularly lack coinpetence or behavioral control is a strongly ingrained social dogina that underlies the special legal treatment accorded mentally disordered persons. ${ }^{19}$ But what is the basis for this belief? A major distinguishing aspect of nost behavior labeled serious mental disorder is that it is inexplicably irrational-it is crazy behavior that inakes little or no sense to others. ${ }^{20}$

15. Developments, supra note 1, at 1212; see generally Wear, Mental Illness and Moral Status, 5 J. MED. \& PHIL. 292 (1980).

16. See State v. Sikora, 44 N.J. 453, 470, 210 A.2d 193, 202 (1965); W. LAFAve \& A. ScotT, Criminal Law 23 (1972).

17. In re Williams, 157 F. Supp. 871, 876 (D.D.C. 1958).

18. Model Penal Code $\$ 4.01$, Comment (Tent. Draft No. 4, 1955).

19. A. Goldstein, The InSanity Defense 9-11 (1967).

20. H. Fingarette \& A. Hasse, Mental Disabilities and Criminal Responsibility 199-239 (1979); Fingarette, Disabilities of Mind and Criminal Responsibility-A Unitary Doctrine, 
When a person behaves in sucl a way, there is a tendency to believe that the person is out of control. ${ }^{21}$ After all, who, in his right mind, would clioose to act crazily?22 Thus, when we cannot make sense of the behavior of another, we believe that there is something wrong with the person, solnething beyond the actor's control in inost cases. ${ }^{23}$ For example, if a patient tells us that lie will not take his medicine because the doctor is a hostile agent trying to poison him, we are likely to believe the patient is mentally disordered-the reason for drug refusal is delusional, after all-and that this refusal of treatment is incompetent because it is the product of the delusion and not of the patient's free, rational choice.

But the assertion that the crazy beliavior of mentally disordered persons is compelled, in contrast to the freely chosen beliavior of normal persons, is a belief that rests on commonsense imtuitions and not on scientific evidence. ${ }^{24}$ Indeed, the degree of lack of behavioral control necessary to justify involuntary commitment is fundamentally a moral, social, and legal question-not a scientific one. ${ }^{25}$ Social and behavioral

76 Colum. L. Rev. 236, 248-52 (1976); Moore, Some Myths about 'Mental Illness,' 32 ARCH. GeN. PSYCHIAT. 1483, 1496 (1975).

21. Rabkin, Opinions About Mental Illness: A Review of the Literature, 77 PsYCHOL. BuLL. 153, 158-59 (1972); Sarbin \& Mancuso, Failure of a Moral Enterprise: Attitudes of the Public Toward Mental IIlness, 35 J. Consult. \& CLIN. Psychol. 159, 159 (1970).

22. If, however, so acting led to a beneficial result, then choosing to act crazily would no longer seem uncontrollable, irrational, or crazy. For example, consider the case of a criminal defendant who feigns insanity to avoid conviction. This was apparently the ploy used by Ezra Pound, aided and abetted by certain psychiatrists, to avoid trial, conviction, and possible execution for treason after the Second World War. Torrey, The Protection of Ezra Pound, PsYcHoL. TODAY, Nov. 1981, at 57.

23. See Morse, Crazy Behavior, Morals, and Science: An Analysis of Mental Health Law, 51 S. CAL. L. REV. 527, 531 (1978).

24. Id. at $553,559-89$.

25. In another context, the author has analyzed this question as follows:

Law is a normative enterprise that treats nearly all persons in all situations as responsible for their acts and often for the natural and probable consequences of those acts. In most cases the law adheres to the commonsense and subjectively experienced view that behavior is a matter of choice: it is the actor's act. Nevertheless, the law acknowledges that all persons are subjected to various biological, psychological, and sociocultural factors or pressures that affect their choices of action. All such factors affect choices, making some choices easy and some hard. As a result, the law recognizes that some behavioral choices may be too hard to serve as the basis for the imposition of legal responsibility ....

While acknowledging that some choices are so hard that it is imappropriate for society to ascribe responsibility for them to the actor, the legal system allows few exceptions to the rule that persons are causally and legally responsible for their behavior. But which choices are too hard?. . . There is no bright line between free and unfree choices. Harder and easier choices are arranged along a continuum of choice: there is no scientifically dictated cutting poimt where legal and moral responsibility begins or ends. Nor is there a higher moral authority which can tell society where to draw the line. All society can do is to determine the cutting point that comports with our collective sense of morality. The real issue is where society ought to draw the line of responsibility-and by whom it should be drawn. 
scientists can only provide information about the pressures affecting an actor's freedom of choice. The law inust determine for itself when the actor is no longer to be treated as autonomous. ${ }^{26}$

In fact, empirical evidence bearing on the question of the control capacity of mentally disordered persons would seem to indicate that mentally disordered persons have a great deal of control over their crazy behavior and legally relevant behavior related to it; ${ }^{27}$ indeed, often they may have as much control over their behavior as normal persons do. ${ }^{28}$ Even in apparently easy cases where it seeins clear that the legally relevant behavior is the product of mental disorder-for example, the delusional person who refuses needed inedication or attacks the doctor because he believes the doctor is a hostile agent-we cannot be sure that the person is incapable, as opposed to unwilling, to behave rationally or to control him or herself. All that is certain is that the person did not behave rationally compared to dominant social standards.

For comparison, imagine the case of a habitually hot-tempered person who takes offense at something his doctor says and threatens to harm the doctor. Is this person more in control or rational than the delusional person? Or, consider the case of a severely ill cardiac patient who refuses to modify dietary, exercise, or smoking habits because the person prefers his or her habitually unhealthy lifestyle. The person's behavior can disrupt the well-being of the family, help drive up health care and insurance costs, and, if the result is an untimely death, impoverish the family. Is this person nore in control or rational than the delusional person, and if so, in what sense? Of course, we all "understand" the behavior of the hot-teinpered person and the cardiac patient, while the behavior of the delusional person inakes no sense whatsoever. Still, there is no conclusive ineans to prove that any of these persons has greater or lesser control than any of the others. Despite this, civil commitment is possible only for the delusional person; the hot-tempered person may be detained only after striking or at-

Morse, supra note 23, at 562 (quoting Morse, The Twilight of Welfare Criminology: A Reply to Judge Bazelon, 49 S. CAL. L. REv. 1247, 1253 (1976)).

The central questiou for our inquiry, then, is whether the choice to behave in legally relevant ways is too hard a choice for society fairly to ascribe inoral and legal responsibility to actors whose legally relevant behavior seems caused by craziness.

26. Hardisty, Mental Illness: A Legal Fiction, 48 WASH. L. Rev. 735 (1973); Suarez, A Critique of the Psychiatrist's Role as Expert Witness, 12 J. For. SCI. 172 (1967); Szasz, Psychiatric Expert Testimony-Its Covert Meaning and Social Function, 20 PsYCHIAT. 313, 315-16 (1957); Waelder, Psychiatry and the Problem of Criminal Responsibility, 101 U. PA. L. REv. 378, 386 (1952). See generally Hunphrey v. Cady, 405 U.S. 504 (1972).

27. Morse, supra note 23, at 561. Einpirical data cannot, however, dispose of the conceptual problein of whether persons have free will. J. MACKIE, ETHICs 203-08 (1977).

28. Morse, supra note 23, at 576 . 
tempting to strike the doctor and the cardiac patient cannot be forced to enter a hospital or to change his or her lifestyle.

There is thus hittle support for the proposition that the mentally disordered, in contrast with normal persons, lack the ability to control their behavior. The mere intuition that the inentally disordered lack control should not be sufficient to deprive such persons of their freedom. A system of involuntary commitinent for only disordered persons therefore cannot be justified on the basis of the mentally disordered's alleged lack of free choice or capability for rationality. ${ }^{29}$

A second possible reason that only crazy persons may be committed is the belief that they are especially dangerous. ${ }^{30}$ If so, society might be justified in institutimg special measures that would make it particularly easy to intervene $m$ the lives of crazy persons for either their own good or the good of society. This arguinent, however, may be disposed of with relative ease. Mental disorder is both an over and undermclusive predictor of dangerousness; most crazy persons are not dangerous and many normal persons are. ${ }^{31}$

Indeed, although it is hard to obtaim firm data on this question, mentally disordered persons are probably no more dangerous than normal persons. ${ }^{32}$ At one point it was believed that inentally disordered persons were especially prone to violence, but later empirical studies

29. I ain not suggesting, of course, that all mentally disordered persons are capable of reasonable rationality and self-control; such a claim would ignore reality. Nevertheless, because the capability for rationality and self-control is distributed along a continuum, most disordered persons ineet the low threshold in these capacities necessary for freedoin from involuntary state mtrusion in a society that so highly values hiberty. Moreover, many people not considered mentally disordered repeatedly behave in ways that are most harmful to themselves and society. Although such behavior is attributed to character or weakness or soine other cause not based on mental disorder, the intuition is that this behavior also is out of control. Yet only those labeled mentally disordered can be massively deprived of their liberty by involuntary hospitalization. The language and conceptual apparatus of the disorder or disease concept is the primary support for this distinction, but in fact the labels are conclusions about alleged lack of control, not proof of it.

The intuitive lunch that the mentally disordered lack control is insufficient support for the system of involuntary civil commitment that distinguishes our examples of the delusional, hottempered, and pliysically ill persons. If mentally disordered persons have significant control over their lives and are reasonably capable of rationality, and if it appears-labels of disorder asidethat many normal persons substantially lack these capaeities, then the disordered are largely indistinguishable from other citizens in these respects. Consequently, they should not be treated differently to their disadvantage in terms of their freedom from confinement and freedom to tive their lives as they choose.

30. Cocozza \& Steadman, The Failure of Psychiatric Predictions of Dangerousness: Clear and Convincing Evidence, 29 RuTGERS L. REv. 1084, 1087-88 (1976); Sarbin \& Mancuso, supra note 21.

31. Rappeport, The Problem of the Dangerousness of the Mentally III, in THE CLINICAL Evaluation of the Dangerousness of the Mentally Ill 3, 4 (J. Rappeport ed. 1967).

32. Chambers, Alternatives to Civil Commitment of the Mentally III: Practical Guides and Constitutional Imperatives, 70 Mich. L. REv. 1107, 1124 (1972); Diamond, The Psychiatric Predlction of Dangerousness, 123 U. PA. L. REv. 439, 444 (1974); Gulevich \& Bourne, Mental Illness and Violence, in Violence AND the Struggle for EXISTENCE 309, 313 (D. Damiels, M. Gilula \& F. 
tended to support the opposite conclusion, which in turn becane the accepted wisdom for inany years. ${ }^{33}$ In the last few years, however, a series of studies has tended to show that ex-inental hospital patients have higher arrest (not conviction) rates than nonpatients. ${ }^{34}$ Such findings have led soine to conclude that mentally disordered persons inay be especially dangerous. But close analysis of the data reveals that prior arrest rather than inental status is the variable that accounts for the recently increased arrest rates among mental patients-patients are now inore likely to have been previously arrested than formerly. ${ }^{35}$ Moreover, ninety percent of ex-patients are not arrested. ${ }^{36}$ In sum, mental patients are not especially dangerous, and, if they are shightly more dangerous than nonpatients, it is not a consequence of their mental disorders. ${ }^{37}$ Finally, the mentally disordered account for inuch less violence in absolute terms than normal persons. Therefore, if social safety is a primary goal of involuntary hospitalization, it will not be served by singling out the inentally disordered.

A third reason given for allowing commitment of only the mentally disordered is that such persons are especially incompetent, that is, incapable of rationally deciding what is in their own best interests. ${ }^{38}$ The concept of incompetence is difficult to analyze, but it is clear that it refers to an inability to decide rationally or to manage one's life, rather than to the fact that the individual in question makes decisions that might be considered irrational or based upon seemingly irrational reasons. In order to protect liberty and autonomy, the legal systein focuses on the decisionmaking process rather than decisional outcoines: ${ }^{39}$ so

Ochberg eds. 1970); Steadman \& Keveles, The Community Adjustment and Criminal Activity of the Baxstrom Patients: 1966-1970, 129 AM. J. Psychiat. 304, 308, 310 (1972).

33. Brill \& Malzberg, Criminal Acts of Ex-Mental Hospital Patients, AM. Psychiat. Assoc. MHS, Supp. 153 (1962); Rappeport, Lassen \& Hay, A Review of the Literature on the Dangerousness of the Mentally III, in The Clinical Evaluation of the Dangerousness of the MenTALLY ILL, 72, 74-76 (J. Rappeport ed. 1967).

34. Rabkin, Criminal Behavior of Discharged Mental Patients: A Critical Appraisal of the Research, 86 Psychol. Bull. 1, 21 (1979).

35. Steadman, Vanderwyst \& Ribner, Comparing Arrest Rates of Mental Patients and Criminal Offenders, 135 AM. J. Psychiat. 1218, 1218 (1978). But see Sosowsky, Explaining the Increased Arrest Rate Among Mental Patients: A Cautionary Note, 137 AM. J. Psychiat. 1602,.160304 (1980).

36. Rabkin, supra note 34, at 26.

37. Morse, supra note 23, at 540, 581, 631. But see Sosowsky, supra note 35. See generally Monahan \& Splane, Psychological Approaches to Criminal Behavior, in 2 CRIMINology REv. Y.B. 17, 36-39 (E. Bittner \& S. Messinger eds. 1980).

38. Morse, supra note 23, at 632-34; Developments, supra note 1, at 1208.

39. Colyar v. Third Judicial Dist. Court, 469 F. Supp. 424, 430-32, 434 (D.C. Utah 1979); Livermore, Malmqnist \& Meehl, On the Justification for Civil Commitment, 117 U. PA. L. Rev. 75, 88 (1968). Of course, process and outcoine cannot always be so neatly separated. Process only becoines significant, typically, in cases where an ontcoine or series of outcoines seems unduly irrational. Mcreover, it will often be assumed that the process unust have been irrational if an 
long as a person is capable of rational decisionmaking and managing, the person will be left free to make irrational decisions or to mismanage his or her life and to suffer the consequences; ${ }^{40}$ only if the person is not so capable does overriding the actor's judgment and substituting the judgment of the state appear justified. Of course, a person who consistently demonstrates bad judgment or gives apparently irrational reasons for his or her decisions is often assessed as being incapable of exercising sound judgment, at least in particular areas of his or her life. Nevertheless, it is generally believed that unless the person is crazy, he or she is probably capable of deciding rationally, even if most of the evidence is to the contrary. ${ }^{41}$

Are the mentally disordered particularly incoinpetent? The question is crucial because imvoluntary commitment substitutes the state's judgment about the necessity for hospitalization (and often for treatment as well) for the judgment of the individual. Although commitment rarely includes a formal finding of legal incompetence at present, it at least implies the judgment that in some cases the person cannot cope or inake decisions in his or ler own best interest. ${ }^{42}$ Indeed, the commitment schemes proposed by Alan Stone and Loren Roth place crucial weight on a person's decisionmaking competence. ${ }^{43}$

There is, however, hittle empirical or theoretical justification for the behef that the mentally disordered as a class are especially mcapable of managing their lives or deciding for themselves what is in their own best interests. ${ }^{44}$ Available empirical evidence demonstrates that the mentally disordered as a class are probably not more incompetent than normal persons as a class. ${ }^{45}$ Indeed, there is no necessary relationship between mental disorder and legal incompetence. ${ }^{46}$ As it was with

irrational decision is reached, even though the individual may be able to provide an apparently rational explanation for the behavior.

40. Morse, supra note 23, at 632-34.

41. See, e.g., Commonwealth v. Mutina, 366 Mass. 810, 815, 323 N.E.2d 294, 297 (1975).

42. R. Allen, E. Ferster \& H. Weihofen, Mental Impairment and Legal IncompeTENCY 32-34 (1968). Contra, Vecchione v. Wohlgemuth, 377 F. Supp. 1361, 1367 (E.D. Pa. 1974) (recognizing that inental disorder does not necessarily imply incompetence), 426 F. Supp. 1297 (E.D. Pa. 1977), 558 F.2d 150 (3d Cir. 1977), cert. denied sub. nom. Beal v. Vecchione, 434 U.S. 943 (1977).

43. A. Stone, Mental Health and Law: A System in Transition 66-76 (1975); see text accompanying notes $145-60$ infra.

44. See Rogers v. Okin, 478 F. Supp. 1342, 1361 (D. Mass. 1979), modified on appeal, 634 F.2d 650 (1st Cir. 1980), cert. granted, 101 S. Ct. 1972 (1981); Rennie v. Klem, 462 F. Supp. 1131, 1145 (D.N.J. 1978), modified and remanded, 653 F.2d 836 (3d Cir. 1981).

45. Buttiglieri, Woodson, Guenette \& Thomson, Driver Accidents and the Neuropsychiatric Patient, 33 J. Consult. \& Clin. Psychol. 381, 381; Howard, The Ex-Mental Patient as an Employee: An On-lhe-Job Evaluation, 45 AM. J. ORTHOPsychiaT. 479 (1975); Tolor, Kelly \& Stebbins, Altruism in Psychiatric Patients: How Socially Concerned are the Emotionally Disturbed?, 44 J. Consult. \& Clin. Psychol. 503, 506 (1976).

46. Morse, supra note 23, at 540-41, 632-34. 
dangerousness, mental disorder is an over and underinclusive indicator: many normal persons are incompetent ${ }^{47}$ and many, if not most, mentally disordered persons are not. ${ }^{48}$ Consequently, the premise of the commitment systein that crazy people are particularly incompetent is unsupported. While some disordered persons are clearly incompetent according to any reasonable criteria, the social goal of reducing the consequences of incompetence is not well-served by allowing involuntary hospitalization, guardianship, or treatment of only the mentally disordered.

A final reason for allowing commitment of only inentally disordered persons is the belief that they are especially treatable. ${ }^{49}$ The mental disorders themselves and the dangerous and incompetent behaviors that allegedly ensue from mental disorder supposedly are particularly amehorable by mental health treatment methods. Although this assertion seems reasonable, once again there is little evidence to support it. ${ }^{50}$ There is every reason to believe that normal persons who are dangerous or incompetent are equally treatable..$^{51}$ Indeed, there is good reason to believe that normality is positively correlated with likelihood of treatment success. ${ }^{52}$ Moreover, the consequent social disabilities, which are in many cases more worrisome than mental health symptoms, are far harder to treat than the symptoms themselves. ${ }^{53}$ Differential treatability is thus not a supportable rationale for allowing imvoluntary commitment of the mentally disordered.

These comments on the lack of self-control, dangerousness, incompetence, and treatability of the mentally disordered do not imply that no seriously mentally disordered person lacks self-control or is dangerous or incompetent as a result of his mental disorder; nor do they mean that the disordered are per se untreatable. A person who is assaultive

47. One in Five Adults Lack Basic Living Skills, Study Finds, L.A. Times, Oct. 30, 1975, § X, at 1 , col. 1 . 1971).

48. See The Mentaliy Disabled and the Law 251-52 (rev. ed. S. Brakel \& R. Rock

49. But cf. Katz, The Right to Treatment-An Enchanting Legal Fiction?, 36 U. CHI. L. Rev. 755,762 (1969) (involuntary treatment not therapeutically effective).

50. A. Stone, supra note 43, at 36-37; Livcrmore, Malmquist \& Meehl, supra note 39, at 86; May, When, What and Why? Psychopharmacotherapy and Other Treatments in Schizophrenia, 17 Comp. Psychiat. 683 (1976). See generally DuBose, Of the Parens Patriae Commitment Power and Drug Treatment of Schizophrenia: Do the Benefits to the Patient Justify Involuntary Treatment?, 60 MinN. L. Rev. 1149, 1167-209 (1976).

51. Livermore, Malmquist \& Meehl, supra note 39, at 86.

52. J. Frank, Persuasion and Healing 188-89 (rev. ed. 1974); W. Schofield, PsychoTHERAPY: THE PURCHASE OF FRIENDSHIP 128-35 (1964).

53. May, supra note 50, at 689; See also White \& Bennett, Training Psychiatric Residents in Chronic Care, 32 Hosp. \& Comm. Psychiat. 339, 339 (1981). Social disabilities refer, for example, to a person's lack of skills to manage personal care or finances, to obtain medical care, to hold a job, or simply to learn to behave reasonably appropriately in social situations. 
because of delusions is of course dangerous. And although lack of selfcontrol and incoinpetence are hard to assess, in some cases a commonsense determination that a crazy person lacks control or is incoinpetent can be inade. Finally, many mentally disordered persons are of course treatable with soine likelihood of success. Both data and theory indicate, however, that the inentally disordered as a class are not particularly lacking in the capability for self-control and rationality, nor are they particularly dangerous, incoinpetent, or treatable. There would thus seein to be little support for an involuntary commitment system that is imposed only on the inentally disordered. ${ }^{54}$ Such a system will neither protect society nor protect large nuinbers of persons from themselves with special efficacy. What such a systein will do is cause large numbers of citizens to lose their liberty based on faulty premises that rob thein of dignity. ${ }^{55}$

At the very least the analysis offered in this section should suggest that if involuntary commitinent of only the inentally disordered can be justified at all, it should be limited to cases of persons who, first, are so clearly crazy that all reasonable persons would agree that their capability for self-control or rationality fails to pass even the lowest of legal

54. One answer is that perhaps normals, too, should be involuntarily coinmitted if they behave in the legally relevant ways that now in part support involuntary hospitalization. This answer is consistent with the case 1 have suggested. But instituting a broad preventive detention scheme applicable to all citizcns would constitute a vast shift in the relative power of the state versus the individual, and it would be an extraordinary infrimgement on liberty in our society. Nor is such a scheine consistent with historical, constitutional, and social values. See Dershowitz, The Origins of Preventive Confinement in Anglo-American Law, 43 U. CIN. L. REv. 781 (1974); Johnson, The Role of Penal Quarantine in Reducing Violent Crime, 24 CRIME \& DeLINQ. 465, 47480 (1978). But see Korematsu v. United States, 323 U.S. 214 (1944), and Hirabayashi v. United States, 320 U.S. 81 (1943) (Japanese relocation cases).

55. Morse, supra note 23 , at 653.

It may be objected at this point that the arguinent is reasonable when applied to all persons who inay be labelled mentally disordered according to the criteria of DSM-III; after all, inany of the categories refer to behavior that is hardly very crazy according to anyone's definition. But the persons who are involuntarily hospitalized are typically very crazy imdeed, and it appears that their capacity for self-control or rationality is far reinoved froin that of the average noncrazy or mildly crazy citizen. It is admittedly diffieult to inake any sense of severely crazy behavior in a large number of instances, and it is hard to beheve that very crazy persons have any control over such craziness and its further behavioral consequences. Yet it is clear, for instance, that delusional people do not always act on their delusions and that in most ways very crazy people act just like normal persons. Moreover, inany seemingly normal persons seem fixed in irrational and repetitive behavior patterns that are destructive of their health, happiness, and welfare. Even if such normal persons can give reasons for their self-destructive behavior that make some sense, it is hard to beheve that these reasous are not rationalizations or that these persons would continue so to act if they could help it. In suin, the argument that the mentally disordered do not specially lack self-coutrol is less intuitively persuasive when it is applied to very crazy persons, but this does not vitiate its conceptual and empirical underpinnings. In any case, if the argument fails when applied to the subclass of severely crazy persons, then the law should only apply to them. Of course, present civil commitment statutes are not so limited. 
thresholds; ${ }^{56}$ second, are so dangerous or incoinpetent, as demonstrated by objective acts, that preventive confinement is clearly and absolutely necessary to prevent grave harm; and, third, are clearly and only treatable on an inpatient basis. Only in such cases can singling out the mentally disordered for involuntary hospitalization be reasonably justified on theoretical and utilitarian grounds. ${ }^{57}$

\section{B. The Involuntary Commitment System Will Produce Unacceptable Numbers of Improper Commitments}

Proponents of commitment often concede that in the past the commitment net ensnared many persons who did not need to be committed. But, they argue, there are persons for whom involuntary commitment is truly appropriate. Involuntary commitment, therefore, should be properly limited rather than abolished. ${ }^{58}$ In that way, the excesses of the past will be avoided, the system will operate fairly, and the small amount of liberty sacrificed will be justified by the benefits flowing to society and those committed. This argument has plausibility and appeal if one accepts, as many do, that the inentally disordered are different enough to warrant a commitment system applicable only to thein and that proper limitation of involuntary commitment is possible. This section challenges the latter assumption and argues that it is highly unlikely that the involuntary commitment system will operate so as to commit only properly committable persons and that, to the contrary, unjustifiably high overcommitment will necessarily result from the existence of any commitment system that applies only to the mentally disordered.

One factor that is likely to lead to the overuse of civil commitment is the use of commitment as a mechanisin for the control of "overflow" deviance. As a social control system, involuntary commitment provides a solution to the problems caused by troublesome, annoying, scary, and weird persons. ${ }^{59}$ Even if such people are not particularly harmful to themselves or others, they often disrupt-frequently se-

56. It should be clear that a diagnosis of mental disorder would not be helpful in assessing this criterion. The question would be whether the person's thoughts, feelings, and actions are so crazy that the assumption about lack of capacity for self-control is clearly reasonable. Morse, supra note 23 , at 559 .

57. There are, of course, also nondisordered persons who meet these three criteria, but here I am accepting, for the sake of argument, the threshold distinction between disordered and nondisordered persons.

58. Chodof, The Case for Involuntary Hospitalization of the Mentally Ill, 133 AM. J. PSYCHIAT. 496, 497 (1976).

59. K. Miller, Managing Madness: The Case Against Civil Commitment 129-31 (1976); Rachlin, Pam \& Milton, Civil Liberties versus Involuntary Hospitalization, 132 AM. J. PsychIAT. 189, 190-91 (1975); see Lamb, Sorkin \& Zusman, Legislating Social Control of the Mentally Ill in California, 138 AM. J. Psychiat. 334, 338 (1981). 
verely-their families, friends, colleagues, and the public. In short, they tend to cause interpersonal problems and to make those around them feel profoundly uncomfortable. The criminal justice system may be unable to control this type of deviance because in inany instances the deviant behavior inay not constitute a crime. ${ }^{60}$ Still, the severity of social disruption and nuisance is undeniable. Involuntary commitment thus satisfies a perceived need to have an alternative system to deal with this type of conduct.

Family and interpersonal problems and the discomfort of others, however, are not sufficient reasons in a free and plurahstic society to deprive people involuntarily of their liberty: the right of people not to be bothered is important, but it is far less weighty than the right of the bothersome person to be free. ${ }^{61}$ Nor will it do to say that we must have commitment for such cases because society will insist on it. To date, few of the "horribles" predicted by opponents of enhanced rights for the disordered have occurred as a result of greater freedom for the disordered. Society has tolerated and can inanage to tolerate crazy behavior without resort to incarceration.

Although limited involuntary commitment laws seek to avoid undue incarceration, the social pressure to incarcerate troublesome, crazy deviants is so powerful that such laws are likely to be misapplied. ${ }^{62}$ People who do not fit the commitment criteria will be lield to do so, and the system will continue to sweep into hospitals persons who are capable of living freely without significant danger to themselves or others. Civil commitinent is such a simple, although unfair, answer to interpersonal, family, and comparatively mild social problems that it is certain to be overused. ${ }^{63}$

Another factor that increases the likelihood of improper overcoinmitment is the difficulty attending proper conceptualization and diagnosis of inental disorder. There is inuch disagreement among mental

60. Monahan, Caldeira \& Friedlander, Police and the Mentally Ill: $A$ Comparison of Commitred and Arrested Persons, 2 INT'L J.L. \& Psychiat. 509, 513 (1979) (only 30\% of persons committed were technically arrestable); Warren, The Social Constructions of Dangerousness, 8 URB. LiFE 359 (1979). But $c$ f. Dickey, Incompetency and the Nondangerous Mentally III Client, 16 CRIM. L. Bull. 22, 29 (1980) (disruptive behavior should not be excused in attempting to understand the problems of the mentally ill).

61. O'Connor v. Donaldson, 422 U.S. 563, 576 (1975). Moreover, it is worth emphasizing that the vast majority of social nuisance and disruption is caused by persons who are not sufficiently disordered to be committable.

62. See sources cited at notes III-12 infra; $f f$. Dickey, supra note 60, at 36 (need to do something about troublesoine behavior leads to use of incompetency commitment where civil commitment is barred). It is also worth noting that more generally powerless persons, such as blacks and the aged, tend to be disproportionately committed. Tomelleri, Lakshminarayanan \& Herjanic, Who are the 'Committed"?, 165 J. Nerv. \& MENT. DiSEASE 288 (1977).

63. K. MLLLER, supra note 59. 
health professionals about how to define and categorize disorders. ${ }^{64}$ Further, there are those who go so far as to claim that mental disorder does not exist, that a medical model of deviant behavior is misguided and perhaps dangerous. ${ }^{65}$ A common theme im many of the criticisms of the medical model is that it is far too easy to declare any deviant behavior to be the symptom of a disorder, thus bringing that behavior within the ambit of the commitment system. ${ }^{66}$

The debate about the medical model and the proper conceptualization of crazy behavior has been imtense for at least two decades and shows little sign of abatimg. ${ }^{67}$ At present, a more medical view seems to have regained its ascendency within the psychiatric profession. ${ }^{68} \mathrm{Nev}$ ertheless, the problems associated with the medical model cannot be gamsaid by discoveries of biological causes for some disordered behaviors or by the apparently clear success of some somatic treatments, most notably chemotherapies, in reducing crazy behaviors im significant numbers of patients. ${ }^{69}$ The controversy concerning the medical model will not disappear, and indeed, it will probably reappear with renewed intensity with the almost inevitable failure of the new biological psychiatry to fulfill the lofty hopes it has engendered. And so long as the debate is unresolved, the group with the power to define disorders will retain the ability to overinclude deviant behaviors as mental disorders. $^{70}$

Even if one accepts the validity of the medical model as a reasonable working model, a related but seemingly decreasing problem is that of diagnostic reliability. Prior to the promulgation of the most recent Diagnostic and Statistical Manual (DSM-III),${ }^{71}$ it was fair to claim on the basis of the research evidence that the reliability of diagnoses of

64. Ennis \& Litwack, Psychiatry and The Presumption of Expertise: Flipping Coins in the Courtroom, 62 CALIF. L. Rev. 693, 697 (1974); Goleman, Who's Mentally Ill?, PSYchol. TodAY, Jan. 1978 at 34-35; R. SPITZER \& D. KLEIN, Definition of Labeling and Mental Illness, in CRITICAL IsSUes IN PSychiatric Diagnosis 1 (1978).

65. T. Szasz, supra note 2; T. Szasz, The Manufacture of Madness (1970). See also T. Sarbin \& J. Mancuso, Schizophrenia: Medical Diagnosis or Moral Verdict? (1980).

66. Morse, supra note 23, at 560; Schwitzgebel, supra note 5, at 50.

67. See, e.g., T. SARBIN \& J. MANcuso, supra note 65; J. WIng, REasoning About MADNESS 140-66 (1978).

68. Psychiatry's Focus Turns to Biology, L. A. Times, July 21, 1980, § 1, at 1, col. 1 (morning final ed.).

69. Morse, supra note 23, at 564-72.

70. The classic historical instance was the debate centered in the American Psychiatric Association over whether homosexual behavior per se was a mental disorder. After intense lobbying by gay rights groups and sympathetic elements within the A.P.A., the organization held a referendum to decide whether homosexuality was a mental disorder. As a result of that vote, behavior that was formerly viewed as a disorder was relabeled normal. For a chronicle of this extraordinary event, see R. BAyer, Homosexuality and American Psychiatry: The Politics of DIAGNOSIS (1981).

71. DSM-III, supra note 14. 
mental disorders, mcluding those considered the most severe, often failed to rise over fifty percent when measured by independent rater agreement. ${ }^{72}$ However, unlike the categories of $D S M-I I,{ }^{73}$ those of $D S M-I I I$ are relatively precisely defined and include specific inclusion and exclusion criteria. Consequently and unsurprisingly, the initial field trials of $D S M-I I I$ have demonstrated far higher reliability than most previous studies. For example, in the second stage of the DSMIII field trials, the reliability coefficients (kappa) for schizophrenia, major affective disorders, and organic brain syndrome-the disorders that are diagnosed in the major proportion of hospitalized patientswere $.81, .80$, and .76 respectively. ${ }^{74}$ Accordingly, there is at least some reason for optimism about the possibility of achieving reasonable accuracy on the threshold involuntary commitment criterion-the presence of mental disorder. ${ }^{75}$

Despite the theoretical possibility of high diagnostic reliability un-

72. Spitzer \& Fleiss, A Re-analysis of the Reliability of Psychiatric Diagnosis, 125 BRIT. J. Psychiat. 341, 344 (1974). This was the case even when the study used clinicians from a major psychiatric research center and precise research diagnostic criteria. Helzer, Clayton, Pambakian, Reich, Woodruff \& Revely, Reliability of Psychaitric Diagnosis: II. The Test/Retest Reliability of Diagnostic Classification, 34 ARCH. GEN. PsychIAT. 136, 139 (1977) (the coefficient of agreement (kappa) for depression was .55, for schizophrenia, .58, and for organic brain syndrome, .29).

73. American Psychiat. Assoc., Diagnostic and Statistical Manual of Mental DisORDERS (2d ed. 1968).

74. DSM-III, supra note 14 , at 470.

75. A. STONE, supra note 43. Despite the mitial favorable findings on the reliability of DSM$I I I$, caution is nonetheless warranted before it can be ultimately concluded either that DSM-III diagnoses are highly reliable or that such higher reliability will even partially solve the overcommitment problem. There are questions one may raise about the field trials. The experimenterdiagnosticians in the field trials were completely self-selected. The principal investigators advertised for field testers in the Psychiatric News, the American Psychiatric Association newspaper that reaches the entire membership, and in other mental liealth publications. Of the 20,000-30,000 psychiatrists reached by these advertisements, 365 volunteered to participate and all wcre accepted. It is virtually certain, therefore, that the field testers were more imterested in diagnostic accuracy than the average practitioner and correspondimgly were unusually careful in their diagnostic work during the field trials. Moreover, although the methodological instructions to the numerous diagnosticians were filled with instructions and admomitions to avoid biased case selection and to maintain rater independence, there was no ongoing direct supervision by the project staff over the groups carrying out the trials. The fullest description of the field trials is DSM-III, supra note 14, at 467-68 (citmg other descriptions as well). Although the description is not clear on this point, a inember of the project staff confirned that the cases were not selected according to an agreed, randomized procedure, but instead were selected on a "catch as catcli can" basis at the various centers performing the field trials (apparently the field testers did not exercise a systematically biased selection procedure either). Telephone conversation with Steven Hyler, M.D., Columbia University, Nov. 4, 1981. Furthernore, the enormous increase in reliabihty over the Helzer study, supra note 72 , seems difficult to explain because, as noted, the Helzer study used both explicit research criteria and, presumably, highly motivated diagnosticians from a major research center. The American Psychiatric Association is to be commended for trying to test $D S M-I I I$ fairly, but one may appropriately wonder if the reliability figures would have been so high if all the field trials used randoni cases and were carefully controlled and supervised. Moreover, it is not at all clear that, even if the field trials are accurate, the apphication of DSM-III in 
der DSM-III, it is unlikely that its detailed guidelines will effectively prevent overcommitment. The very high rehability achieved under controlled research conditions may not be able to be matched by diagnosticians in the hurly-burly of everyday practice; caution is warranted until the results of reliability studies of the general use of DSM-III are available. Furthermore, the diagnostic criteria of $D S M-I I I$ are still sufficiently vague to allow a diagnostician with biases for lospitalization or treatment to fit a large number of persons into the inost serious categories. ${ }^{76}$ Moreover, many persons who may legitimately be given a severe diagnosis may still not be sufficiently crazy to warrant involuntary hospitalization. Thus, although it is reasonable to be optimistic about the benefits of $D S M-I I I$, its use is by no means a guarantee against overcommitment.

Even if the mental health professional is able to diagnose mental disorder accurately, the problem of the legal system's treatment of that diagnosis remains. Mental illness or disorder is often not defined for legal purposes. ${ }^{77}$ Will all conditions called mental disorder support involuntary commitunent (if the behavioral component is also met), or should ouly severe mental disorder be sufficient? If only severe disor-

general practice will be equally reliable. For a thorougl critique of the reliability of $D S M-I I I$, see J. Ziskin, 1 Coping with Psychiatric and Psychological Testimony 138-44 (3d ed. 1981).

Moreover, although the diagnostic entities of $D S M-I I I$ may be more reliable than their predecessors, there is still reason to question whether the new entities are valid. A psychiatric disorder is said to be valid if it is distinguishable from other disorders not only by its facial criteria, but also by its course, family patterns, pathoplyysiology, specific treatment response, and the like. Feighner, Robins, Guze, Woodruff, Winokur \& Munoz, Diagnostic Criteria for Use in Psychiatric Research, 26 ARCH. GEN. PSYCHIAT. 57, 57 (1972) (for the vast majority of psychiatric disorders, there are no conclusive anatomical or chemical signs to validate the presence of a disorder). To date, in my view and the view of others, substantial research evidence for the validity of most DSM-III categories is lacking. See Overall \& Hollister, Comparative Evaluation of Research Diagnostic Criteria for Schizophrenia, 36 ARCH. GEN. PSYCHIAT. 1198, 1198 (1979); Reply by Overall and Hollister to Letter to the Editor, 36 ARCH. GEN. PSYCHIAT. 1382 (1979); J. ZISKIN, supra, at 137-38.

76. See DSM-III, supra note 14 , at 6 :

Another misconception is that all individuals described as laving the same mental disorder are alike in all important ways. Although all the individuals described as having the same mental disorder show at least the defining features of disorder, they may well differ in other important ways that may affect clinical management and outcome.

For example, note that persons diagnosed "schizophrenic" according to DSM-III, id. at 181-93, may exhibit quite different behaviors depending on which subtype of schizophrenia the individual allegedly has. (It may be noted, too, that despite the wide differences in the criteria for the different subtypes, the field test reliability figure of .81 was calculated on the basis of agreement about any form of schizophrenia.) Simple inspection of the criteria for schizophrenia and its subtypes discloses that there are few precise quantitative criteria, and thus a given person with schizophremia, as intimated above, "nuay well differ in other important ways," such as the overall degree of craziness and social disability evidenced by the person.

77. See, e.g., Lelos, Courtroom Observation Study of Civil Commitment, in Civil CommitMENT AND Social Policy 102, 103-04 (A. McGarry et al. eds. 1978) (study of application of statute in Massachusetts). 
der is sufficient for legal commitment purposes, how is severity defined and who should decide which disorders fit the category of "severe"? ${ }^{78}$

A third basis for the belief that commitment criteria will be overapplied is that the relevant behavioral component standards are too vague and require predictions that are beyond the present capability of mental health professionals or anyone else. Standards such as "dangerousness" or "need for hospitalization" have no generally agreed upon meaning among lay persons or professionals. ${ }^{79}$ Of course, there is likely to be a great deal of agreement about extreme cases, ${ }^{80}$ but such cases are unusual. Thus, it may be claimed, each witness, lay or professional, along with each factfinder, imjects his or her own private meaning into the criteria, rendering the system essentially lawless.

It would be possible to ameliorate such vagueness by rewriting the criteria to allow commitment only if rather specific behavioral criteria were met. ${ }^{81}$ For mstance, the dangerousness criterion might be written

78. See A. STONE, supra note 43, at 47, 48; Stier \& Stoebe, Involuntary Hospitalization of the Mentally Ill in lowa: The Failure of the 1975 Legislation, 64 IowA L. REV. 1284, 1382 (1979).

There are undeniably serious problems with a "medical model" of disordered behavior, with diagnostic reliability in psychiatry, and with the legal definition of mental disorder. These problems, however, need not unduly undermme the proper workability of a commitment system. To the extent the law continues to rely on mental health categories to answer legal questions, such as who should be cominitted imvoluntarily, it remaims at the mercy of the vagaries, unreliability, and internecine disputes of mental health science. Once freed from such reliance, identification of the inentally disordered becoines less problematic. I subınit that for involuntary commitment purposes the law is seeking to identify those persons who seem so severely disturbed, so crazy, that the intuition about the lack of behavioral control appears justified. Even if there are conceptual problems with the concept "mental disorder," there are certamly some people who behave so inexplicably irrationally, so crazily, that society is perhaps warranted in beheving that something is "wrong" with such persons. Identification of these persons, rather than being a scientific matter, requires a social, moral, and legal assessinent that these people are fit subjects for preventive detention because they behave in an mexplicably irrational manner betokening lack of fundamental autonoiny. Morse, supra note 23, at 553; but $\mathcal{f f}$. Addimgton v. Texas, 441 U.S. 418,430 (1979) (discussing standard for burden of proof in coininitınent proceedings). If the legal identification of mental disorder were placed on this common sense social basis, fewer "incorrect" legal decisions would result and the liberty of citizens would not depend on the particular diagnostic theories and skills of the testifying mental health professionals. Morse, supra note 23, at 560 . This solution, however, would not be a panacea. Judges and juries might still differ widely about who is sufficiently crazy and overcommitment could still result. But the system would be asking the proper questions, and over time a relatively clear legal standard of severe disorders might develop.

79. Menzies, Webster \& Butler, Perceptions of Dangerousness among Forensic Psychiatrists, 22 COMPREHENSIVE PSYCHIAT. 389, 391 (1981) (the "striking feature" of the responses of forensic psychiatrists to a questioumaire asking thein to define dangerousness "was the wide variability of perceptions of dangerousness"); Simon \& Cockerham, Civil Commitment, Burden of Proof, and Dangcrous Acts: A Comparison of the Perspectives of Judges and Psychiatrists, 5 J. PsYCHIAT. L. 571, 573-74 (1977); see Schwitzgebel, Treatment and Policy Considerations, in Crvil COMMITMENT AND Social Policy 25, 33 (A. McGarry et. al. eds. 1981); Stier \& Stoeber, supra note 78, at 138590.

80. Simon \& Cockerham, supra note 79 , at 588-90.

81. Stamus v. Leonhardt, 414 F. Supp. 439, 451 (S.D. Iowa 1976); $c$. Goldstein \& Katz, Dangerousness and Mental Illness, Some Observations on the Decision to Release Persons Acquitted 
and interpreted to mean only substantial physical danger-for example, death or serious bodily harm to oneself or others as evidenced by a recent (e.g., within the past seven days) act or attempt. While such a standard is no more vague than many substantive criminal law criteria, a few observations are $\mathrm{m}$ order. In a free society, preventive detention should be authorized, if at all, only for serious harms. Additionally, persons whose dangerousness is evidenced by acts or attempts can be removed from society by the criminal justice system. However, if dangerousness is evidenced only by a threat (or less), the question of the predictability of real harm, discussed in detail below, ${ }^{82}$ is raised.$^{83} \mathrm{Fi}$ nally, there is the fundamental question of whether it is the proper role of the state to intervene massively in the life of an individual to prevent the person from doing harm to him or herself. Thus, philosophical and political objections to paternalistic commitment are not resolved by developing more precisely defined criteria that refer to relatively specific behaviors. Although less vague criteria ensure that the system will operate more fairly, the system's foundation remains unsound.

When commitment laws authorize preventive detention, predictions of future behavior are almost always required. For example, commitment criteria often require that the person is "likely" to be a danger to self or others. ${ }^{84}$ On occasion no qualifying phrase referring to probability will be found, and a person may be committed if he or she is simply "dangerous to others." 85 There are two related problems with these criteria: first, it is rarely if ever clear what specific probability of the requisite harms is required; ${ }^{86}$ and, second, only poor predictive ability exists.

The former difficulty could be remedied by nore precise statutory specification of the probability required. What probability of harm is required (and which harms are required) is a political, legal, and constitutional question. It is clear, however, that in a free society there should be a high probability of the occurrence of the harm prior to any preventive detention. ${ }^{87}$ But how high is sufficient?" ${ }^{88}$ If "likely" or similar standards are interpreted to mean $51 \%$ probability, this will mean

by Reason of Insanity, 70 Y ALE L.J. 225, 235-39 (discussing criteria for commitment following a defendant's acquittal by reason of insanity). See generally Fuller, Two Principles of Human Association, in Voluntary Associations 3 (J. Pennock \& J. Chapman eds. 1969).

82. See text accoinpanying notes $90-96$ infra.

83. A. Stone, supra note 43, at 29; Stier \& Stoebe, supra note 78, at 1384-85; Note, Overt Dangerous Behavior as a Constitutional Requirement for Involuntary Civil Commitment of the Mentally Ill, 44 U. CHI. L. Rev. 562, 584-85 (1977).

84. E.g., Iowa CoDE ANN. \$229.1 (West 1979).

85. Schwitzgebel, supra note 5, at 50-51; see, e.g., CAL. WELF. \& INST. CoDE $§ 5250$ (West Supp. 1981).

86. Schwitzgebel, supra note 5 , at 51 .

87. O'Connor v. Donaldson, 422 U.S. $563,573-76$ (1975). 
that persons may be incarcerated when there is just slightly more than a 50-50 chance that they will actually cause the specified harms. Assuming that the probability data are accurate, it is therefore possible that just under half the people committed will not pose the requisite danger in fact. This number of wrongly committed "false positives" is completely unjustified in a society that values liberty. Most informed persons would probably agree that the "correct" probability required for preventive detention is much higher, say, in excess of $80 \%$. But even then, it should be noted, one person in five will be unnecessarily committed. It might be argued that the probability of harm required and the degree of harm required should be inversely related: the greater the harm predicted, the lower the probability of its occurrence that is required. ${ }^{89}$ But if such an inverse shing scale were permissible, the probability of harm required for even great harms should still be quite high.

Even if the predictive criteria are defined inore clearly and at a sufficiently high probability level, there is little evidence that future legally relevant behavior, especially in the long term, can be accurately predicted by anyone ${ }^{90}$ except in a few clear cases. Most cases will not be clear and many false predictions will result. Indeed, studies of the prediction of violence to others demonstrate that an accuracy rate of $30-40 \%$ is unusually high. ${ }^{91}$ For predictions of suicide, an accuracy rate of about 20\% appears to be the upper limit of present predictive skill. ${ }^{92}$ Of course, if the probability of harm required for commitinent is lowered enough, fewer improper commitments will ensue. But, since most persons would probably agree that preventive detention should not be authorized on the basis of a low probability of harm, the prediction problem cannot be solved in this fashion.

88. See, eg., McGarry \& Schwitzgebel, Introduction, in Civil Commitment AND Social Policy 1, 5-6 (A. McGarry et al. eds. 1978); Schwitzgebel, supra note 5.

89. Monahan \& Wexler, A Definite Maybe: Proof and Probability in Civil Commitment, 2 LAW AND Human Behavior 37, 38-39 (1978); $f f$. Genego, Goldberger \& Jackson, Parole Release Decision Making and the Sentencing Process, 84 YALE L.J. 810, 872-76 (1975) (arguing that similar salient factor scale used in parole decisions is constitutional in spite of high error).

90. Cocozza \& Steadman, supra note 30; Diamond, supra note 32; Monahan, Prediction Research and the Emergency Commitment of Dangerous Mentally III Persons: A Rcconsideration, 135 AM. J. Psychlat. 198 (1978).

91. Monahan, The Prevention of Violence, in Community MENTAL HeAlth AND THE CRIMINAL JUSTICE SYSTEM 13, 17 (J. Monahan ed. 1976). Accuracy rates of under $10 \%$ are not uncoinInon. The American Psychiatric Association has admitted that psychiatrists are poor predictors of long range violent behavior. Amicus Curiae Brief for the Alnerican Psychiatric Association at 1416, Estelle v. Smith, 101 S.Ct. 1866 (1981).

92. Mackinnon \& Farberow, An Assessment of the Utility of Suicide Prevention, 6 SuICIDE and Life-Threatening Behavior 86 (1976); see Pierce, The Predictive Validation of a Suiclde Intent Scale: A Five Year Follow-up, 139 BRIT. J. PsychIAT. 391 (1981) (considerably lower accuracy, even when predicting clearest cases). 
The problem is particularly acute in the involuntary commitment context where the imcreased use of dangerousness criteria has amplified the necessity for relymg on predictions to make commitment decisions. Many false predictions appear inevitable, and it is virtually certain that there will be many more false positives than false negatives since mental health professionals tend to err in the direction of overpredicting rather than underpredicting legally relevant behavior. ${ }^{93}$ For many reasons, professionals are more likely incorrectly to believe that harm will occur or that involuntary treatment in a closed institution is necessary than incorrectly to believe the opposite. ${ }^{94}$ As a result, lack of predictive accuracy leads far more often to incorrect commitment than to incorrect release. The improper incarceration of a vast number of hapless citizens who safely could and properly should remam at liberty is the unfortunate result.

Inaccurate predictions create a powerful objection to involuntary

93. J. Monahan, The Clinical Prediction of Violent Behavior $44-50$ (1981); Fagin, The Policy Implications of Predictive Decision-making: 'Likelihood' and 'Dangerousness' in Civil Commitment Proceedings, 24 Pub. Policy 491, 511-14 (1979); Monahan, supra note 91, at 20-21; McGarry \& Schwitzgebel, supra note 88, at 4; Shah, Dangerousness: A Paradigm for Exploring Some Issues in Law and Psychology, 33 AM. Psychol. 224, 227-28 (1978); Wenk, Robison \& Smith, Can Violence be Predicted?, 18 CRIME AND Delinquency 393, 398-402 (1972); $\mathrm{H}$. Steadman, The Statistical Prediction of Violent Behavior: Measuring the Costs of a Public Protectionist versus a Civil Libertarian Model, 5 L. \& HuM. BEHAv.-(in press). As Steadman's paper points out, this will be true whether one adopts a basically libertarian or control model for deciding whom to commit; see Menzies, Webster \& Butler, supra note 79, at 394 (despite wide variability in psychiatric definitions of dangerousness and other criticisms of the utility of the dangerousness concept, forensic psychiatrists "were still confident in their capacity to utilize the concept in an accurate and socially valuable manner").

A possible caveat to the negative assessment of predictive accuracy is necessary when considering predictions of short term behavior based on immediately past behavior. John Monahan lias suggested that predictive accuracy in such situations is likely to be quite good and therefore should not vitiate the propriety of short term emergency commitment. Monahan, supra note 90. This suggestion is plausible and sensible, but to date there is almost no research on the question and one study that might seem to support it was insufficiently controlled. Rofman, Askinazi \& Fant, The Prediction of Dangerous Behavior in Emergency Civil Commitment, 137 AM. J. PsYchiAT. 1061 (1980).

Even if Professor Monahan is correct, his thesis still does not make strong inroads in the case against involuntary commitment. First, if the emergency situation involves harm to others, the behavior will properly invoke the criminal justice system. I and others, e.g., A. STONE, supra note 43 , at 36-37, 70, consider that the most appropriate system to deal with such behavior. The other major type of emergency situation where predictions may be reasonably accurate will be cases of acute, active, and clear suicidal actions. If short term emergency commitment is allowed in response to such cases, this would create only a possibility for very limited involuntary commitment. These cases will also meet the three clear critcria for ever justifying commitment discussed at notes 56-57 and accompanying text supra. In any event, most predictions are not made in such clear cases. Finally, Professor Monahan's suggestion does not apply to release decisions.

94. Dershowitz, Psychiatry in the Legal Process: A Knife that Cuts Both Ways, 4 Trial 32-33 (1968); cf. Scheff, Decision Rules, Types of Error and Their Consequences in Medical Diagnosis, 8 AM. Behav. Scientist 97 (1963) (physicians "too often place patients in the 'sick role' who could otherwise have contmued in their normal pursuits."). 
commitment because a society with a strong preference for liberty should seek to minimize mcorrect mvoluntary commitments, even at the risk of increasmg the number of "incorrect" rejections of commitment. ${ }^{95}$ The analogue to the criminal justice system, of course, is that our society does "not view the social disutility of convicting an innocent man as equivalent to the disutility of acquitting someone who is guilty." 96 Until predictive accuracy becomes immeasurably greater, the involuntary civil commitment system will result in unacceptable numbers of unjust commitments.

A final reason that overcommitment is inevitable is the procedural laxness that apparently characterizes commitment proceedimgs nearly everywhere, including those jurisdictions where the law requires rather stringent protections. Hearings tend to be perfunctory, rarely applymg fully the procedural protections required; there is not a reasonably complete exploration of either the factual basis for commitment or the possibility of less restrictive placements. ${ }^{97}$ Furtherinore, since appeals are infrequent, judges are left relatively free to apply substantive criteria too loosely and to fail to insist on the requisite procedural safeguards. Most importantly, the lawyers who represent the allegedly inentally disordered often fail to act in a fully adversary manner, even when trained to do so. ${ }^{98}$ Finally, although the standard of proof required for involuntary commitment under the Constitution is stricter than the civil preponderance standard, ${ }^{99}$ it creates a much higher risk of wrongful commitment than the criminal standard of "reasonable doubt." 100

95. But cf. Addington v. Texas, 441 U.S. 418, 428-29 (1979) (standard of proof in civil commitment proceedings can be lower than that required for conviction in criminal cases).

96. In re Winship, 397 U.S. 358, 373 (1970) (Harlan, J., concurring).

97. See State ex rel. Meinunel v. Mundy, 75 Wis. 2d 276, 249 N.W.2d 573 (1977); sources cited in notes 111-12, 185 infra; studies cited in Morse, supra note 23, at 536 n.16. See also Luckey \& Berman, Effects of a New Commitment Law on Involuntary Admissions and Service Utilizatlon Patterns, 3 L. \& Human BeHav. 149, 159 (1979) (raising the burden of persuasion in commitment cases did not change the commitment rate, suggesting that the burden of persuasion was not being strictly applied).

98. Poythress, Psychiatric Expertise in Civil Commitment: Training Attorneys to Cope With Expert Testimony, 2 LAW \& HuMAN Behavior 1, 8-12 (1978).

99. Addington v. Texas, 441 U.S. 418 (1979).

100. See In re Winship, 397 U.S. 358 (1970).

Many civil commitment cases have required the reasonable doubt standard, e.g., Lessard v. Schmidt, 349 F. Supp. 1078 (E.D. Wis. 1972) (subsequent procedural history set forth in note 4 supra); Conservatorship of Roulet, 23 Cal. 3d 219, 590 P.2d 1, 152 Cal. Rptr. 425 (1979); Superintendent of Worcester State Hosp. v. Hagberg, 374 Mass. 271, 372 N.E.2d 242 (Mass. 1978). Critics of the reasonable doubt standard have claimed that the standard is so high that it would be impossible to commit anyone. But such criticism confuses the probability of harm required to commit with the burden of persuasion necessary to prove that probability. Monahan \& Wexler, supra note 89. It is also contradicted by the experience of jurisdictions where the reasonable doubt standard applies. Zander, Civil Commitment in Wisconsin: The Impact of Lessard v. Schmidt, 1976 WIS. L. Rev. 503, 508. 
It is sometimes argued, by those who are aware of the overcommitment danger, that the problem is not serious. Even if some persons are wrongly committed because they are not significantly dangerous to themselves or others, it is contended, these persons probably are mentally disordered and will therefore benefit from a regime of hospital care and treatment. ${ }^{101}$ This argument must fail for at least two reasons. First, society has decided that provision of treatment does not outweigh liberty interests $\mathrm{m}$ those cases that do not meet the statutory criteria for commitment; wrongful commitment is unjustified, abusive, and stigmatizing even if treatment is provided. ${ }^{102}$ Second, as discussed im greater detail im the next section, state mental hospitals (and many private hospitals) are unlikely to provide quality care and treatment, even to those wlio arguably need it the most. ${ }^{103}$

It is also claimed by some that professional review and the concern of family and friends are effective buffers agamst erroneous commitment. This argument was made by the Umited States Supreme Court im Addington $v$. Texas in support of its holding that the Constitution did not require a standard of proof for mvoluntary commitment as high as the criminal "beyond a reasonable doubt" standard. ${ }^{104}$ This line of reasoning is stunningly mistaken, however. Truly adequate professional review or care is a rarity in the public hospital system (and in some private hospitals), ${ }^{105}$ and, as much researcli demonstrates, comimitment often occurs im cases where the person to be committed has no family or friends. ${ }^{106}$ Moreover, where families and friends exist, they are usually only too glad to have the bothersome person removed from circulation. ${ }^{107}$ The checks on erroneous commitment suggested by the Supreme Court simply do not exist to a substantial degree.

The Court observed further in Addington that a person debilitated by mental disorder already suffers from stigma and diminished liberty

101. A good fact situation on which this type of argument might be based is presented by In re Hatley, 291 N.C. 693, 231 S.E. 633 (1977). Ms. Hatley was evidently clearly disordered, but her proven dangerous behavior was merely careless backing up of her automobile. On appeal, Ms. Hatley was released. This case is also a good example of the use of involuntary hospitalization to remove a difficult and perhaps disruptive family member.

102. O'Connor v. Donaldson, 422 U.S. 563, 573-76 (1975).

103. See text accompanying notes $115-35$ infra.

104. The Court noted that a standard higher than the civil (preponderance) standard was required because civil commitment involved substantial liberty interests and stigma. 441 U.S. 418, 431-32 (1979).

105. See text accompanying notes 121-25 infra.

106. C. Warren, The Court of Last Resort: Mental Illness and the Law 259-61 (unpub. manuscript, to be published in 1982 by U. Chicago Press). See also Lelos, supra note 77, at 152-53.

107. Indeed, one highly respected mental health court judge once confidcd to me that he was always willing to rule against commitment if family or friends would come to court and indicate a willingness to care for the allegedly committable person. Unfortunately, this rarely occurred. 
by reason of the disorder. ${ }^{108}$ Therefore, the Court naively concluded, "it cannot be said that it is much better for a mentally ill person to 'go free' than for a normal person to be committed." 109 In a word, erroneous commitment is serious, but it is not a grave social error. Such a behef is sadly mistaken. It is true that a severely disordered person is stigmatized to some degree and has restricted hfe choices in the community. However, it is no less true that involuntary hospitalization is a further extraordinary restriction on liberty that should be avoided at all costs. Moreover, in many cases, an mcrease im stigma also results: until a person is hospitalized involuntarily, there is no authoritative public labeling and recording that the person is mentally sick. Hospitalization is an unfortunate outcome for alinost any citizen and is egregiously larmful for those who do not meet the statutory criteria for commitment. The Court's argument is astonishing; only by ignoring or mischaracterizing the social circumstances of those committed, the vast overcommitment that now occurs, the quality of the public (and many private) hospitals, and the consequences of hospitalization, can it be so cavaher about wrongful commitment and about the balance of state and imdividual interests.

In sum, for a variety of reasons--the desire to control deviance, difficulties in the proper definition and diagnosis of mental disorder, vagueness of commitment standards, difficulties in accurately prcdictimg future behavior, and procedural laxity-the involuntary civil commitment system will produce unacceptably high numbers of improper commitments and thus will contimue to function as an unjust system. This will be true even in those jurisdictions that have reforined their commitment statutes im an attempt to limit their application only to those persons who allegedly truly require involuntary hospitalization. ${ }^{110}$

The claim that a high likelihood of overcommitment is inevitable is supported by empirical studies of the application of reforined commitment statutes. ${ }^{111}$ Careful studics demonstrate that as many as half

108. 441 U.S. 418,429 (1979).

109. The Court therefore refused to draw the analogy between the criminal justice systemwhere it is better to acquit the guilty than convict the innocent-and the involuntary commitment system. Id.

110. This problem is a major difficulty with the commitment schemes proposed by Drs. Stone and Roth, which are discussed at notes 145-60 and accompanying text infra.

111. Hiday, Reformed Commitment Procedures: An Empirical Study in the Courtroom, 11 L. \& Soc. 654-55, 662-63; Lipsett \& Lelos, Decision Makers in Law and Psychiatry and the Involuntary Commitment Process, 17 Comm. Mental Health J. 114, 120 (1981) (only 58\% of patients committed after court hearings met the combined commitment criteria); Stier \& Stoebe, supra note 78, at 1370-71; Warren, Involuntary Commitment for Mental Disorder: The Application of California's Lanterman-Petris-Short Act, 11 L. \& Soc. REv. 629, 647 (1977) (major finding was that the statutory criteria for civil commitment were not strictly applied); Wickham, Hospitalization of the Men- 
the persons committed in a jurisdiction do not meet the jurisdiction's statutory criteria for commitunent. ${ }^{12}$ Thus, both theory and data indicate that there is little reason to believe that civil commitment can be reasonably limited. As the studies show, statutory reform does not seein to inake inuch difference. At best, as suggested above, one can try to develop precisely defined standards that would be satisfied by rare, clear cases. ${ }^{113}$ If such standards were accoinpanied by rigorous, adversary procedures, reasonable limitations on wrongful commitment might result. Such standards and procedural behavior appear unlikely to be instituted, however; and, as we have seen, statutory reform does not appear to make much difference.

Is a system that improperly imcarcerates a substantial percentage of its inmates-perhaps as many as half or more-supportable in our society? It is clear that if the standards and procedures of the criminal justice system led to a fifty percent erroneous conviction rate, the system would be blatantly unconstitutional. ${ }^{114}$ Until recently, the justifiability of the involuntary commitment system has been accepted without inuch question and the burden of demonstrating its inequities has been firmly on the opponents of involuntary hospitalization. The burden of persuasion in the commitment debate should now shift to the proponents of the system to delnonstrate that commitment can be appropriately limited. If they cannot, our duty to protect the liberty of all persons must lead us to forego commitment in those few cases where many persons might agree that it is warranted. Unless the systen can be demonstrably reformed, too hittle benefit will be provided at the expense of far too much deprivation of hiberty.

\section{The States Will Not Provide Adequate Care and Treatment to Involuntarily Committed Persons}

The relatively lax standards and procedures for the deprivation of liberty in the involuntary commitment system are often thought to be justified on the ground that the system aims to do good for the sick

tally III in Idaho and the Need for Reform, IDAHo L. REv. 2II, 230-3I (1980). See generally Chambers, Community Based Treatment and the Constitution; the Principle of the Least Restrictive Allernalive, in Alternatives to Mental Hospital Treatment 23, $25-26$ (L. Stein \& M. Test eds. 1978).

112. Lelos, supra note 77, at 180; Stier \& Stoebe, supra note 78, at 1371-90; Wickham, supra note 111, at 230-31; Psychiatric News, Nov. 18, 1977, at 1, col. 3. See also Hiday \& Markell, Components of Dangerousness: Legal Standards in Civil Commitment, 3 INT'L J.L. \& Psychiat. $405,410,412$ (1980) (only 55.3\% of cases met Lessard standard for dangerousness; if restrictive criteria for dangerousness were used, only $7.5 \%$ of cases were commitable).

113. See text accoinpanying notes 81-83 supra.

114. See Patterson v. New York, 432 U.S. 198, 208 (1977); In re Winship, 397 U.S. 358, 36465 (1970). 
recipients of its ministrations. ${ }^{115}$ Indeed, the involuntary commitment system is allegedly distinguishable from the criminal justice system because commitment has and achieves benign, therapeutic aims. ${ }^{116}$ It seems inhumane to prevent needy persons from receiving services because of excessively stringent substantive and procedural requirements for involuntary hospitalization.

A crucial buttress for this argument is the contention that proper care and treatment will be provided to persons who are cominitted. Accordingly, it nuust be asked whether the promise of adequate care and treatment is eurrently being fulfilled and whether the promise is likely to be fulfilled in the future. These questions are especially pertinent if one considers the generally negative attitudes the public holds toward the nentally disordered and the almost universally insufficient public resources allocated to their care.

Even under ideal conditions, current neental health treatments are unlikely to "cure" more than a handful of those committed of their deviant behavior. There is general agreement, first, that nuost nuental health treatments, especially those useful for severely disordered persons, anehorate symptoins rather than curing allegedly underlying illnesses, ${ }^{117}$ and second, that all treatments are frequently unsuccessful and are sometimes even harmful. ${ }^{118}$ Furthernore, reducing syniptoms rarely causes major improventent in the broad range of social disabilities that led to the person's involuntary commitnent. ${ }^{119}$ For this reason and because mental disorder is often not causally linked to legally relevant behavior, successful treatinent of niental disorder does not guarantee the diminution of the legally relevant behaviors such as dangerousness or inconpetence that are also required for commitment. ${ }^{120}$

Moreover, there are simply not sufficient funds to provide any sub-

115. Addington v. Texas, 441 U.S. 418, 431 (1979); French v. Blackburn, 428 F. Supp. 1351, 1359-60 (M.D.N.C. 1977); Livermore, Malmquist \& Meehl, supra note 39, at 77.

116. Addington v. Texas, 441 U.S. 418, 428 (1979).

117. Committee on Research, Group for the Advancenent of Psychiatry, Pharmacotherapy and Psychotherapy: Paradoxes, Problems and Progress 279-81, 427 (1979); Scheff, Medical Dominance: Psychoactive Drugs and Mental Health Policy, 19 AM. BeHav. Scientist 299, 301-03 (1976).

118. Schwitzgebel, The Right to Effective Mental Treatment, 62 CALlF. L. Rev. 936, 938 (1974); see H. STrupp, S. Hadley \& B. Gomes-Schwartz, Psychotherapy for BetTer or WORse 11, 119 (1977); Jeste \& Wyatt, Changing Epidemiology of Tardive Dyskinesia: An Overview, 138 Aм. J. Psychiat. 297 (1981); Klawans, Getz \& Perlick, Tardive Dyskinesia: Review and Up. date, 137 AM. J. PsYchiat. 900 (1980).

119. May, supra note 50, at 689-90. See A. StoNe, supra note 43, at 213-15.

120. See Morse, supra note 23, at 637-38; Nuehring, Thayer \& Ladner, On The Factors Predicting Rehospitalization Among Two State Mental Hospital Patient Populations, 7 ADMIN. MENTAL Health 247, 266-68 (1980); Rabkin, supra note 34, at 25-26; Rosenblatt \& Mayer, The Recidivism of Mental Patients: A Review of Past Studies, 44 AM. J. ORthopsychIATRY 697 (1974). 
stantial fraction of patients with the type of services that would yield the optimum chance of improving their symptoins, not to mention their general psychosocial disabilities. For the most part, our public (and many private) hospitals treat their patients almost entirely by removing disordered persons from their supposedly stressful environments, by prescribing psychotropic medication with more or less indifferent care, ${ }^{121}$ and by providing a purportedly therapeutic milieu. Even providing maximally beneficial chemotherapy requires expert staffing that is beyond the resources of most public hospitals. More general therapeutic services to remedy psychosocial disabilities are highly labor intensive $^{122}$ and would require funding that is literally unimaginable at present. But without social rehabilitation, it is highly likely that patients will simply revolve back into the system, again to be rendered less symptomatic by chemotherapy, but still lacking the skills to inake a successful adjustment in the community.

Many hospitals are not even able to provide minimally adequate custodial care. Even in "advanced" states that supposedly maintain the best hospitals and provide the best services, revelations of inadequate and sometimes inhumane care and treatment have surfaced to shock the public. ${ }^{123}$ It is well to remember that the gruesome conditions in Alabama hospitals exposed in the Wyatt cases ${ }^{124}$ were occurring in the 1970 's, not the 1870's, and that even today inhumane and antitherapeutic conditions contimue. ${ }^{125}$

The inadequate conditions of public inental hospitals have been a feature of state mental health care for over a century. ${ }^{126}$ Many of the

121. See, e.g., Kaufman, The Right to Treatment Suit as an Agent of Change, 136 AM. J. Psychiat. 1428, 1429-30 (1979); Mason, Nerviano \& De Berger, Patterns of Antipsychotic Drug Use in Four Southeastern State Hospitals, 38 Diseases NERV. SYS. 541 (1977). See generally Gillis \& Moran, An Analysis of Drug Decision in a State Psychiatric Hospital, 37 J. CLIN. Psychol. 32 (1981); Gillis, Lipkin \& Moran, Drug Therapy Decisions: A Social Judgment Analysis, $169 \mathrm{~J}$. Nerv. \& Mental Disease 439 (1981).

122. See, e.g., G. Paul \& R. Lentz, Psychosocial Treatment of Chronic Mental PaTIENTS (1977).

123. See, e.g., N.Y. Times, Oct. 9, 1977, $\S 4$, at 5, col. 3; Gilliam, 36 More Mental Hospital Deaths Questionable, L.A. Times, Nov. 20, 1976, § 1, at 1, col. 1.

124. Wyatt v. lreland, 3 MeNTAI DisAB. L. RPTR. 403 (M.D. Ala. 1979); Wyatt v. Stickney, 334 F. Supp. 1341 (M.D. Ala. 1971), enforced by 344 F. Supp. 373 and 344 F. Supp. 387 (M.D. Ala. 1972), aff'd in part, rev'd and remanded in part on other grounds sub nom. Wyatt v. Aderholt, 503 F.2d 1305 (5th Cir. 1974); Wyatt v. Stickney, 325 F. Supp. 781 (M.D. Ala. 1971).

125. Flakes v. Percy, 511 F. Supp. 1325 (W.D. Wis. 1981); Wyatt v. Ireland, 3 MenraL DISAB. L. RPTR. 403 (M.D. Ala. 1979).

126. J. Talbot, The Death of the Asylum: A Critical Study of State Hospital MANAGEMENT, SERvices, AND CARE 2-4, 18-22, 47-83. Even when conditions are not brutally inluunane, life in state mental hospitals is often depersonalizing, dehumanizing, and unpleasant, and it may often be antitherapeutic. W. COCKERHAM, SOCIOLOGY OF MENTAL DISORDER 274-86 (1981) (citing research literature and first person accounts); R. STUART, TRICK OR TREATMENT 2134 (1970); J. WING, ReAsoning ABout MADNESs 26-27, 131-32 (1978); but see Johnstone, Owens, 
psychiatrists are poorly qualified, if "qualified" at all;: ${ }^{127}$ pliysical conditions and staffing are inadequate; ${ }^{128}$ and satisfactory treatment is a 1nyth. ${ }^{129}$ Periodic exposés and calls for reform have not yet led to acceptable improveinent. Although courts have shown a willingness to supervise public mental hospitals when the level of care provided drops beneath a minimally humane level of decency, ${ }^{130}$ there is still no evidence that legislatures are willing to allocate the money necessary to ensure optimum care and treatment. ${ }^{131}$ Indeed, states faced with right to treatment decrees that force them to expend far greater resources on their patients have responded by "dumping" the patients into the community ${ }^{132}$ instead of treating them witli the degree of care and expertise dictated by decency and medical ethics. This is not to say that there lave not been improvements in state hospital care; it is simply to underscore the reality of inadequate care and treatment nearly everywhere. Arguments that what is available is better than nothing are unacceptable. People who are locked up because they are allegedly disordered must be treated properly. If they are not, we slould admit

Gold, Crow \& MacMillan, Institutionalization and the Defects of Schizophrenia, 139 BRIT. J. PsYCHIAT. 195 (1981). The classic work on life in mental hospitals and other "total institutions" remains E. GoFFMAN, Asylums 1-320 (1961).

127. A. Stone, Psychiatric Abuse and Legal Reform: Two Ways to Make a Bad Situation Worse, INT. J. L. \& PsYchlat.-(in press) (at 29 in Browning Hoffman Memorial Lecture delivered at the University of Virginia School of Law, June 12, 1981). Many state hospital psychiatrists are foreign-trained and are clearly less qualified than American graduates. In addition, they have problems speaking and understanding English, skills that are crucial to psychiatric practice. Torrey \& Taylor, Cheap Labor from Foreign Nations, 130 AM. J. PsychIAT. 428, 429 (1973); Talbott, The Problems and Potential Roles of the State Mental Hospital, in STate MENTal Hospitals: Problems AND Potentials 21, 23 (J. Talbott ed. 1980). On the problem of staffing state hospitals, see generally Torrey \& Taylor, supro.

128. Knesper \& Hirtel, Strategies to Attract Psychiatrists to State Mental Hospital Work: Results from a Survey of Potential Employees, 38 ARCH. GEN. PsychIAT. 1135 (1981). The critical understafing problem was most recently exposed in Bower, Understaffing Severe in State Hospitals Nationwide, Psychiatric News, Sept. 18, 1981, at 1. It appears that the primary "therapists," the direct care providers in state hospitals, are nonprofessional aides. Birnbach, Back Ward Society, 1981: Implications for Residential Treatment and Staff Training, 32 Hosp. \& CoMM. PsYcHIAT. 550,551 (1981) (reporting on the experience in New York State). The reasons for the shortage of well qualified psychiatrists in state mental hospitals seem clear: low status, poor conditions, insufficient budgets, lack of adequate treatment programs, and all the other probleins besetting state hospitals. See J. TALBOTT, supra note 126, at 82-83; Talbott, supra note 127, at 22-26.

129. See New York State Ass'n. for Retarded Children, Inc. v. Rockefeller, 357 F. Supp. 752, 768 (E.D.N.Y. 1973).

130. Halderman v. Pennhurst State School \& Hosp., 446 F. Supp. 1295, 1326-29 (E.D. Pa. 1977), 451 F. Supp. 233 (E.D. Pa. 1978), modified, 612 F.2d 84 (3d Cir. 1979), rev'd and remanded, 100 S. Ct. 1351 (1981); Wyatt v. Stickney, 325 F. Supp. 781 (M.D. Ala. 1971), 334 F. Supp. 1341 (M.D. Ala. 1971), enforced by 334 F. Supp. 373 and 344 F. Supp. 387 (M.D. Ala. 1972), affd in part, rev'd and remanded in part sub nom. Wyatt v. Aderliolt, 503 F.2d 1305 (5th Cir. 1974).

131. Chambers, supra note 111, at 26,36. But $\mathcal{C f}$. Kaufman, supra note 121, at 1430-31 (citing examples of increased appropriations for mental health as a result of riglt to treatment suits).

132. Brown \& Bremer, Inadequate Means to a Noble End: The Right to Treatment Paradox, 6 J. Psychiat. \& Law 45, 58-59 (1978); N.Y. Times, Nov. 18, 1979 \& 1, at 1, col. 5. 
that the major goals of involuntary hospitalization are preventive detention and warehousing and proceed to analyze the system on that basis.

Improvements in treatment techniques are unlikely to provide a solution. Although mental health treatments are definitely improving, no major breakthrough is in sight. ${ }^{133}$ Even if the level of efficacy increases sharply in light of new discoveries, it is doubtful that the new treatments will be cheap or easy to administer. Even adequate chemotherapy, a relatively cheap and easily administered modality, is currently beyond the capability of most public hospitals. If new treatments are efficacious but costly, $m$ the light of past history there is hittle reason to beheve that legislatures will vote the funds necessary to provide these treatments at a level consonant with reasonable psychiatric and psychological skill.

There is one answer to the appalling state of affairs in our public hospitals that has some surface appeal: if commitment were limited to the few extreine cases of severe disorder where it seems warranted, then treatment resources would not be spread as thin and those committed involuntarily might be adequately cared for and treated. In order for services to patients to improve, however, states should not reduce their funding of hospitals in response to a decrease in the patient population- - an extraordinarily unlikely event. In addition, the treatinent provided would still be unlikely to alleviate general psychosocial disabilities. The costs of treatment plans that could alleviate those disabilities would be so enormous that it is doubtful states would be willing to spend that much money, especially for so few patients. Moreover, even if the best treatinent resources now available were offered, unany patients would not improve. Lastly, as argued above, it is highly unlikely that cominitınent could be limited to those few polar cases where commitinent is warranted. ${ }^{134}$ Putting strict limits on coinmitment is thus unlikely to cure the shortcomings in hospital treatment and care.

Until and unless, first, legislatures show a greater willingness to allocate inoney to public inental patients; second, truly qualified mental health professionals demonstrate a willingness to enter the public hospital system in great numbers; and, third, mental health treatments improve greatly, the bemign and therapeutic aims of the imvoluntary commitment system will remain unattained. Both society at large and the mental health professions are to be blamed for this scandalous state

133. For example, there have been no major discoveries of new psychotropic medications for about a decade. On the other hand, mental health professionals have clearly learned how to use the available drugs more effectively.

134. See text accompanying notes 58-114 supra. 
of affairs. The inadequate funding of hospital and community mental health services is an indication of both social distaste for the inentally disordered and a lack of social commitinent to humnane treatment. Involuntary hospitalization as currently practiced will not alleviate chronic disorders and social disabilities that will otherwise lead to a lifelong series of commitments, nor will it restore its mmates to hives of productive happiness. The short term reduction of symptoins, although useful, is simply not adequate treatment. Therefore, to maintain that involuntary commitment is ultimately beneficial to the vast majority of incarcerated patients is to propagate a cruel inyth. ${ }^{135}$

\section{Hospitalization Is Not Necessary for the Efficacious Treatment of the Vast Majority of Involuntarily Committed Patients}

Almost all mental health treatments now available can be provided as efficaciously and usually more cheaply in less restrictive community settimgs than in closed hospitals. ${ }^{136}$ Startimg at the lowest end of the "treatment" spectrum, custodial care can be provided easily in the

135. It is not claimed that involuntary hospitalization is never beneficial or that involuntarily hospitalized patients uniformly hold negative views of their hospital experience-such a claim is contradicted by some reasonable evidence. E.g., L. BACHRACH, DEINSTITUTIONALIZATION: AN ANalytical. Review and Sociological Perspective 8 (1976) (citing sources); Gove \& Fain, $A$ Comparison of Voluntary \& Committed Psychiatric Patients, 34 ARCH. GEN. PsyCHIAT. 669, 675 (1977) (committed and voluntary patients both improved after hospitalization, but committed patients improved shightly more; both groups favorably evaluated the hospitalization experience); Toews, el-Guebaly \& Leckie, Patient's' Reactions to Their Commitment, 26 CAN. J. Psychiat. 251 (1981); Weinstein, Patient Attitudes Toward Mental Hospitalization: A Review of Quantitative Re. search, 20 J. HEALTH \& SOC. BEHAvioR 237, $251-52$ (1979) (no control for commitinent status of patients, however). But see Essex, Estroff, Kane, McLanahan, Robims, Dresser \& Diamond, On Weinstein's "Patient Attitudes Toward Mental Hospitalization: A Review of Quantitative Research" (Comment on Weinstein, J.H.S.B., Sept. 1979), 21 J. Health \& Soc. Behavior 393 (1980). Weinstem's defense of his study is The Favorableness of Patients'Attitudes Toward Mental Hospitalization (Reply to Comment by Essex et al.), 21 J. HEALTH \& SoC. BEHAvioR 397 (1980). Weinstein also notes, however, that a large proportion of patients had negative or ambiguous altitudes and that he beheves that his findings do not "speak for or against institutionalization, either for or against patients' rights." Id. at 400.

Despite the few favorable findings such as these, however, the statements in the text are an accurate reflection of the general reality of inental hospital treatment.

136. L. BACHRACH, supra note 135, at 23 n.27 (citing sources); Becker \& Schulberg, Phasing Out State Hospitals-A Psychiatric Dilemma, 294 NEw ENG. J. MED. 255, 260 (1976); Test \& Stein, Community Treatment of the Chronic Patient: Research Overview, 4 SchizopHrenic Bull. 350, 351 (1978); Weimman \& Klemer, The Impact of Community Living and Community Member Intervention on the Psychotic Patient, in Alternatives to Mental Hospital. Treatment (L. Stein \& M. Test eds. 1978); see sources cited at note 142 infra. But $\mathscr{C}$. Sheridan \& Teplin, Recidivism In Difficult Patients: Differences Between Community Mental Health Center and State Hospital Admissions, 138 AM. J. Psychiat. 688, 689 (1981) (difficult psychiatric patients referred to community mental health centers, $56 \%$ of whom were hospitalized, had reduced lengths of stay and subsequent hospitalizations compared to patients admitted to state hospitals; hospitalization was initially necessary for a inajority of community patients despite the greater range of services available at the community mental health centers). See generally L. BACHRACH, supra note 135. 
community in decent board-and-care-type facilities. There is little reason why the prescription of medication or the provision of convulsive, psychological, and social therapies also cannot be accomplished on an outpatient basis. Research evidence supports the view that hospitalization, especially long term hospitalization, is rarely necessary and is often antitherapeutic. ${ }^{137}$ Many disordered persons would probably be quite willing to accept good outpatient treatments, nursing visits, or other reasonable interventions if they were offered and explained by caring and careful professionals who behaved respectfully towards the disordered. ${ }^{138}$

It has been suggested that hospitalization is necessary because neither courts nor lawyers have the ability to discover and coordinate the less restrictive community services that admittedly would be efficacious if they were utilized. ${ }^{139}$ Although there is a present lack of resource information and coordination, one cannot innagine a weaker argument in favor of the necessity of depriving a person of liberty. The difficulty in gathering infornation about community treatment resources and coordmating a treatunent plan is substantially outweighed by the individual's interest in avoiding unnecessary involuntary commitment. Judges, mental health advocates, and allied social service staff plainly will have to educate themselves and learn to create sensible community treatment alternatives.

Some courts have held that the use of the least restrictive alternative is constitutionally compelled in the treatment process, ${ }^{140}$ and some

137. Stier \& Stoebe, supra note 78, at 1292; Test \& Stein, Alternatives to Mental Hospital Treatment, in Alternatives to Mental Hospital Treatment 43, $43-44$ (L. Stein \& M. Test eds. 1978); see Chambers, Alternatives to Civil Commitment of the Mentally Ill: Practical Guides and Constitutional Imperatives, 70 MicH. L. REv. 1107, 1126-30 (1972); Rosenblatt \& Meyers, supra note 120, at 700. See generally E. GofFMan, supra note 126, at 3-124.

Persons who are too disabled to look after themselves minimally and to offer an opinion on hospitalization may be treated as nonprotesting and hospitalized for their own safety and care. Additionally, some hospital capacity should exist for those who voluntarily want inpatient services and who understand the costs and benefits of such services compared to the alternatives.

138. This might be especially true if the prospective patient or service recipient were sure that seeking help for mental disorder or its consequent disabilities would not lead to incarceration. Nevertheless, it must be adinitted that there will be a population of chronically disordered persons who will refuse or be unable to utilize community care. Schwartz \& Goldfinger, The New Chronic Patient: Clinical Characteristics of an Emerging Subgroup, 32 Hosp. \& CoMm. PsYCHIAT. 470 (1981). This Article adinits that there will be costs to abolishing involuntary hospitalization, but argues that, on balance, the benefits will exceed those costs. In any event, as will be discussed below, there are probably not enough staff and resources to treat all the severely disabled patients who want and can utilize resources. See note 179 and accompanying text infra.

139. Zusman, The Need for Intervention: The Reasons for State Control of the Mentally Disordered, in C. Warren, supra note 106 , at 5 \& 33.

140. Stamus v. Leonhardt, 414 F. Supp. 439 (S.D. Iowa 1976); Lynch v. Baxley, 386 F. Supp. 378 (M.D. Ala. 1974); Lessard v. Schınidt, 349 F. Supp. 1078, 1103 (E.D. Wis. 1972) (subsequent procedural history set forth in note 4 supra); Chambers, supra note 111, at 28, 29. 
legislatures, including Congress, have utilized the same doctrine as a matter of social policy. ${ }^{141}$ The doctrine is based upon the sound assumption that if the primary purpose of commitment is truly to treat people and not simply to remove thein from the commumity, hospitalization is almost never justified. In those cases where it may appear justified, creative use of community resources is likely to be as efficacious and cheaper than imvoluntary hospitalization, ${ }^{142}$ and far less restrictive of the disordered person's liberty. In other words, if the

141. 42 U.S.C. $\$ \$ 6001-6081$ (1976 \& Supp. 1979); see, e.g., TENN. Code ANN. § 33-604 (1979).

142. Dickey, Gudeman, Hellman, Donatelle \& Grinspoon, A Follow-up of Deinstitutionalized Chronic Patients Four Years Afler Discharge, 32 Hosp. \& Comm. Psychlat. 326 (1981) (all but 2 of 27 subjects preferred their current living situation to life in the state hospital); Stem \& Test, Alternatives to Mental Hospltal Treatment: 1. Conceptual Model, Treatment Program, and Clinical Evaluation, 37 ARCH. GEN. PsyCHLAT. 392 (1980) (empirical study and citing other studies); sources cited at note 137 supra; see Washburn, Vannicelli, Longabaugh \& Scliefi, $A$ Controlled Comparison of Psychiatric Day Treatment and Inpatient Hospitalization, 44 J. Consult \& CulN. PsyCHOL. 665 (1976). Test and Stein also found that a total in-community program resulted in no more burden on the family or community than the traditional approach. Test \& Stein, Alternative to Mental Hospital Treatment: III. Social Cost, 37 ARCH. GEN. Psychiat. 409 (1980) (results explained in part by large amount of support services provided to patients, families and community members). A number of studies lave demonstrated that community services are cheaper than lospitalization. Murphy \& Datel, A Cost-Benefit Analysis of Conmunity Versus Institutional L/ving, 27 Hosp. \& Comm. Psychiat. 105 (1976); Sharfstein \& Nafziger, Communily Care: Costs and Benefits for a Chronic Patient, 27 Hosp. \& Comm. Psychiat. 170 (1976); Weisbrod, Test \& Stein, Alternative to Mental Hospital Treatment: II. Economic Benefi-Cost Analysis, 37 ARCH. GEN. Psychlat. 400 (1980) (extensive community treatment more expensive than lospitalization, but, overall, community treatment cheaper). See also Sheehan \& Atkinson, Comparative Costs of State Hospital and Community-Based Inpatient Care in Texas: Who Benefits Most?, 25 Hosp. \& Coмm. Psychiat. 242 (1974). But see Borus, Deinstitutionalization of the Chronically Mentally IIl, 305 New EnG. J. MEd. 339, 340-41 (1981). See generally Frank, Cost-Benefit Analysis in Mental Health Services: A Review of the Lilerature, 8 ADMIN. MENTAL HEALTH 161 (1981). The most recent study whose preliminary findings support the benefits and cost-effectiveness of community treatment is Boyd, McGill \& Falloon, Family Participation in the Community Rehabilitatlon of Schizophrenics, 32 Hosp. \& COMM. Psychiat. 629 (1981). The methodology of many of the outcome studies of deinstitutionalization lias been criticized, however, suggesting the need for some caution in reaching conclusions. Braun, Kochansky, Shapiro, Greenberg, Gudeman, Johnson \& Slore, Overview: Deinstitutionalization of Psychiatric Patients, A Critical Review of Outcome Studies, 138 AM. J. PsychiAT. 736 (1981); but see Pasaminick, Letter to the Editor, Deinstitutionalization Studies: Some Clarifications, 138 AM. J. PsyChIAT. 1633 (1981).

One reason that many patients can now live relatively successfully outside state lospitals is the provision by the federal government of Supplemental Security Income (SSI). Lamb \& Goertzel, The Long-Term Patient in the Era of Community Treatment, 34 ARCH. GEN. Psychlat. 679,682 (1977). Unfortunately, SSI can also foster dependency and act as a disincentive to the provision of effective social and vocational rehabilitation programs. Emerson, Roehford \& Shaw, Economics and Enterprise in Board and Care Homes for the Mentally III, 24 AM. BEHAV. SCIENTIST 771,783 (1981) (referring to the current board and care system); Lamb \& Rogawski, Supplemental Security Income and the Sick Role, 135 AM. J. PsYchlat. 1221 (1978). This is a difficult and not entirely soluble problem, but its solution would seem to be the provision of intensive rehabilitation services and counseling to wean the disordered person away from a life of nonproductive dependence. Of course, to the extent that society fails to provide adequate services in the coinmunity, there will be no solution to this problem. Nevertheless, a life of nonproductive dependency in freedom is preferable to sucl a life in a locked hospital. 
necessary alternatives were seriously pursued, most persons now committable would not need to be committed even if they met the statutory criteria.

Of course, society can fail, as it does now, to provide services to people at liberty in the community as inuch as it fails to provide them to incarcerated patients. The condition of many "demstitutionalized" ex-patients in the community is a national disgrace. ${ }^{143}$ Moreover, knowledge of mental health science is as rudimentary in the community as it is in the hospital. But if society is willing to expend the resources and to inake the humane commitment to caring for and treating people who may need and want such services, these services can be provided as efficaciously and more cheaply in the freedom of the community. ${ }^{144}$ The mvoluntary commitment system liardly seeins justified by the tiny fraction of cases that perhaps can be treated best im a hospital, especially im light of the justifiable pessimisin about hospital conditions and treatment and the inevitably high risk of overcommitment.

\section{II}

\section{New Proposals for Involuntary Commitment}

In recent years, two eminent psychiatrists concerned with mental health law, Drs. Alan A. Stone and Loren H. Roth, have proposed similar new commitment scheines that atteinpt to strike a fair balance be-

143. The characterization, "national disgrace," is mine. For a description and analysis of the situation that led to that characterization, see Arnhoff, Social Consequences of Policy Toward Mental Illness, 188 Sc1ENCE 1277 (1975); Kirk \& Therrien, Community Mental Health Myths and the Fate of Former Hospitalized Patients, 38 Psychiat. 209 (1975); Scull, $A$ New Trade in Lunacy: The Recommodification of the Mental Patient, 8 AM. BEHAV. ScIENTIST 741, 743-44 (1981); sources cited at note 132 supra.

Some commentators suggest that instead of deinstitutionalization, what has in fact occurred is "transinstitutioualization," the relocation of former state lospital patients into different facilities such as nursmg homes or board and care hoines. Scull, supra, at 744-50; Warren, New Forms of Social Control: The Myth of Deinstitutionalization, 8 AM. BEHAV. ScIENTIST 724, 726-30 (1981). This phenomenon is simply another indication of the all too often scandalous societal response to the dignity and needs of the mentally disordered.

144. It is not suggested that the proper provision of voluntary and community services is easy or that providing them will produce normal behavior in chronically, severely disordered persons. Such services are not a panacea. But to the extent effective treatments are available, they can be provided without involuntary lospitalization.

If society made the commitment to providing reasonable care to its disordered persons in the community, mental health care might becone more expensive than it is at present. The greater expense would probably not be created, however, by the high costs per patient of community treatment compared to hospitalization. Rather, the increase would be the result of providing adequate treatment to vastly greater numbers of persons. I assume that if fine services were freely available in the community, there would be great denuand for such services. Nevertheless, the cost per patient of community services is probably cheaper than the cost of hospitalization. See note 142 supra. A resultant increase in the use of services because they are reasonable and available is hardly a reason to cut off such services to needy people. 
tween liberty and paternalism. ${ }^{145}$ Both authors recognize the enormous deprivation of liberty involved in involuntary hospitalization and therefore propose laws that they believe would limit commitment to those cases where a true inedical need is apparent or where society's interest in commitment is overwhelming. Drs. Stone and Roth wish psychiatrists to be returned to their proper role as caring, treating professionals, and each of their analyses is inarked by wisdoin, honesty, compassion, and restraint. Their proposals, however, ultimately suffer from soine of the same shortcomings as existing systems, and thus should not be adopted. To support this conclusion, Part II will first describe their proposals (by focusing on the specific language of the Roth proposal, which includes the Stone proposal in shightly modified form) and will then consider thein in light of the analysis presented in Part I.

The preferred basis for commitinent in the Stone-Roth proposal is parens patriae based on imcoinpetence. ${ }^{146}$ Drs. Roth and Stone want to hospitalize and treat involuntarily only those persons who are terribly disordered, suffering, and incompetent. More particularly, their proposal only recommends commitment when 1) the person suffers from a severe and reliably diagnosed mental disorder; 2) the immediate prognosis for the person is inajor distress unless treatment is provided; 3 ) the mental disorder "substantially impairs the person's ability to understand or communicate about the possibility of treatment"; and 4) the risk/benefit ratio of treatment is such that a reasonable person would consent to a brief, e.g., six week, trial of treatment that is renewable once for another six weeks. ${ }^{147}$ Thus, the Stone-Roth proposal adopts the traditional inodel of doctor-patient relationships wherein the purpose of the relationship is the alleviation of suffering by voluntarily accepted treatment, except where the patient is desperately needy and incapable of rationally deciding whether to accept treatment.

Neither Dr. Rotl1 nor Dr. Stone tries to justify extensively the limi-

145. A. Stone, supra note 43, at 65-69; Roth, A Commitment Law for Patients, Doctors, and Lawyers, 136 AM. J. Psychiat. 1121 (1979).

146. Adoption of a parens patriae model is clearly opposed to the present dominant national trend towards adopting a dangerousness model. Judicial attitudes show a preference for the latter model because it allows preventive detention of "dangerous" persons who can be briefly institutionalized and "treated," rather than burdening the already overcrowded criminal courts. Blooin, Shore \& Treleaver, Oregon's Civil Commitment Statute: Stone's "Thank You Theory"-A Judicial Survey, 7 Bull. AM. ACAD. Psychiat. \& L. 381, 387 (1979).

Dr. Roth's proposal includes a preventive detention form of commitment for those who are dangerous, but persons committed under this model cannot be treated involuntarily unless they are also incompetent. Dr. Stone explicitly eschews commitments solely for dangerousness, although it appears that soine people who are dangerous to self may meet his "suffering" criterion. Dr. Roth's dangerousness proposal will not be discussed because it does not differ extensively from relatively libertarian-oriented dangerousness models now being adopted or suggested.

147. Roth, supra note 145 , at 1122. 
tation of the commitment proposal to only the mentally disordered. They appear to assume that the mentally disordered are specially incompetent or that the incompetence of the inentally disordered is soinehow significantly different from the inconipetence of apparently normal persons. This assumption is of course widely accepted, but its systeinatic defense is rarely attempted: the conclusion is simply made time and again. As this Article has delnonstrated, however, this conclusion is not warranted. Until a persuasive, nonconclusory case is made out for special treatment of the mentally disordered, a more intelligent conclusion is that involuntary commitnent of only this class of citizens is not supportable theoretically.

Assuming for the sake of argument that paternalistic commitment and special treatment of the inentally disordered are both justified, the question renams: Will the Stone-Roth proposal work? To answer this question, the proposal's commitment criteria nust be examined.

The first criterion, that the person suffers fron a rehably diagnosed major disorder, is probleinatic. As suggested earlier, reliance on the categories of mental disorder creates too much opportumity for discretion by not identifying proper candidates for involuntary commitment with sufficient precision. Moreover, a person with a reliably diagnosed severe disorder is not necessarily crazy enough to need coinmitment. ${ }^{148}$ If the remaming criteria are inore crucial, a certain degree of leeway on the threshold criterion may not pose a serious problen. Nonetheless, the threshold criterion of mental disorder undercuts the theoretical validity of the whole enterprise by failing to distinguish adequately the special class to whoin involuntary commitment should apply.

The central criterion for commitnent is an immediate prognosis of "major distress" if treatment is not provided. ${ }^{149}$ Even if a person is severely disordered and imcompetent, commitment will not be possible without this prognosis. But what is the definition of (avoidable) major distress? Is intense psychological pain necessary or sufficient? Would severe synuptonıatology leading to nuajor disruption in family life, career, or reputation suffice if unaccompanied by intense psychological pain? How is major distress, however defined, to be ineasured? How accurately can mental health professionals predict immediate major distress absent treatnuent? What data are pertinent to this crucial prediction?

As should be apparent froin these questions, it will be almost impossible to apply the criterion of major distress in a way that avoids

148. See notes 71-76 and accompanying text supra.

149. Dr. Stone also uses the term "suffering." A. Stone, supra note 43 , at 70. 
improper commitment. The definition of distress will differ widely among both mental health professionals and legal decisionmakers; value judgments about the degree of distress that warrants commitment are bound to imtrude. Moreover, it is doubtful that there is sufficient hard data to vitiate the prediction problem, ${ }^{150}$ and clinical wisdom or hunch should not suffice as evidence to support imvoluntary commitment in our society. In sum, the major distress criterion mevitably will produce discretionary application and, with it, unacceptable overcommitment. ${ }^{151}$

The Stone-Roth incompetency criterion requires that the person's diagnosed illness substantially impair his or her ability to understand or to commumicate about the possibility of treatment. Before discussing the standards for this criterion, an observation about the requisite causal connection between the illness and behavioral disability is in order: we do not know, im general, when a psychiatric illness "causes" other behaviors. What we do know is that crazy behaviors-mexphicably irrational thoughts and feelings - are sometimes clearly implicated in other behaviors. ${ }^{152}$ Take, for example, the person who refuses medication because of a belief that the doctor is a hostile agent trying to poison him. Obviously the person is unable reasonably to weigh information about the medication because of the crazy belief. One could say that it is the patient's paranoia that causes the lack of understanding, but im fact, the crazy belief is the cause. Paranoia, after all, is diagnosed on the basis of behavioral criteria-it is a shorthand for a confluence of behaviors ${ }^{153}$ rather than the name of an entity with a defined morbid anatomy or pathophysiology. The question of incompetence is better posed without reference to the cause of the putative incompetence; when reference to the cause is required, the question should be asked in terms of the person's capability for rationality concerning the treatment issue. ${ }^{154}$

In applying the "understanding" standard in the incompetence cri-

150. To be of any use, the data must be relevant to the legal definition of major distress and sufficiently precise to allow the legal decisionmaker to assess the probable accuracy of the prediction.

151. The issue of the "avoidability" of major distress is related to the "availability of treatment" criterion and to the "reasonable person" criterion for imposing treatment on imcompetent patients. These issues will therefore be discussed together. See note 159 and accompanying text infra.

152. Morse, supra note 23, at 577-82.

153. DSM-IIl, supra note 14 , at $195-98$.

154. Dr. Stone would place the burden of offering a reason for treatment refusal on the disordered and suffering person. In order for the patient to be declared incompetent, the mental health professional must "demonstrate that the refusal is irrational and is based on or related to the diagnosed illness . . . ." A. STONE, supra note 43, at 68. Reasons that are not a product of the illness-those not based on misperceptions of reality-inust be respected even if they appear irrational to the mental health professional. Id. In brief, the test is, "Does the patient's objection to 
terion, the Stone-Roth proposal suggests using the following alternative tests:

(1) Does the patient understand the generally agreed upon consequences (the potential benefits and the potential risks) both of being treated and of not being treated?

(2) Does the patient understand why a particular form of treatment is being considered or recommended in his case? ${ }^{155}$

These are surely among the relevant questions to ask to determine if a person is competent to decide whether to accept treatinent, but neither test is self-evidently the right one. Instead of asking whether the person in fact understands, it might be more proper to mquire if the person is capable of understanding. ${ }^{156}$ Furthermore, the very definition of "understand" is problematic. Does it mean smiply the ability to rearticulate the information provided in a fashion that demonstrates that the person has comprehended the information in a reasonably intelligent way? Or, does it require that the person have affective or emotional understandimg (whatever that might be) as well? How much understanding, however defined, is sufficient to support a finding of legal competence and how is it measured? It is of course true that inany legal standards are frustratingly vague and difficult to apply, but in this case a deprivation of liberty for up to twelve weeks is at stake. It appears all too likely that the vagueness of the "understanding" test will ensure that its definition will vary enormously and that value judgments will affect the commitment decision. ${ }^{157}$ However sound the question asked is im theory, in practice decisions about "understanding" will often be arbitrary and will produce unacceptable amounts of overcommitment. $^{158}$

treatment seem irrational and based on his illness?" Id. at 69 . Thus, the provability of a causal connection is implicitly accepted by Dr. Stone.

155. Roth, supra note 145 , at 1122 . Note that both Drs. Roth and Stone term the allegedly imcompetent person a patient. See also note 154 supra. A person, however, does not become a patient nntil imcompetence is proven. This imprecise use of terminology is not a major problem, but the choice of words covertly begs important questions.

156. People with the ability to behave rationally often behave irrationally, even when they are admonished not to. In practice, the determination of whether a person is capable of certain behavior will be based on whether he or she actually behaves that way. Nevertheless, the distinction should be preserved and decisionmakers should be required to examine the capability for understanding im a broader set of contexts. See notes 38-48 and accompanying text supra. If a "capability for rationality" test is not adopted, I should prefer that the decisionmaker ask simply whether the person's reason for treatment refusal is crazy. This may seem preposterously simplistic, but it is the real question in issue, and it avoids the question begging involved im asking whether lack of understanding is a product of the person's alleged disorder.

157. See generally Roth, Meisel \& Lidz, Tests of Competency to Consent to Treatment, 134 AM. J. PsychIAT. 279 (1977).

158. The third disjunctive test for competence in the Stone-Roth proposal-"Does the patient express a choice for or against treatment?"-seenus much less problematic. Roth, supra note 145, at 1122. Indeed, as discussed at text following note $161 \mathrm{infra}$, a patient in dire physical danger 
The fourth, and final, Stone-Roth criterion can be broken down into two related treatment requirements: (1) treatment that would prevent immediate major distress must be available, and (2) the available treatment must be such that a reasonable person would accept it in hight of the risk/benefit ratio under the circumstances. The second requirement is by far the more troublesome. The reasonable person test is once more an invitation to overly discretionary decisionmaking. Such tests are used throughout the law, but, again, the degree of deprivation of liberty makes the potential cost to the individual much higher here than in most other situations.

A more particular danger is that reasonableness will be judged by comparing the treatment available in public institutions against no treatment at all. If the risk/benefit ratio utilized does not consider state of the art treatment or even the average treatment provided by good private practitioners or hospitals, the minimal treatment available at inost public institutions will be considered acceptably good, thus facilitating a finding that a reasonable person would accept such treatment. This standard, however, is far too low. Reasonable persons who understood the degree to which they would be "shortchanged"-albeit perhaps helped somewhat -in a minimal institution might well refuse imvoluntary hospitalization and treatment. ${ }^{159}$ The question should not be whether involuntary hospitalization would be efficacious, but whether it would be sufficiently more effective than treatment in less restrictive settings to justify the deprivation of hberty involved. The decisionmaker should be aware that what is being offered will typically be considerably less than what is available in private institutions and no nore than what is available in a community setting.

In summary, although the Stone-Roth proposal asks most of the right questions under a parens patriae approach, it is theoretically unjustified and practically unworkable. No systematic argument is

who expresses no preference about treatment could be regarded as nonprotesting and treated accordingly.

159. Dr. Roth properly notes the possibility of a competent person making a "living will" or otherwise declaring that if he or she becomes mcompetent, involuntary treatment is not desired. Id. at 1123. Such preferences would be respected. One might also ask, however, why a legal decisionmaker should not employ a subjective test even in the absence of a living will or similar declaration. (Dr. Roth mentions this possibility, but does not examine it in detail. Id.) In some cases, it will be relatively clear that an incompetent person who previously made no statements about the issue would lave expressed a preference not to be treated. A person who, while competent, had consistently refnsed all forms of inedical treatment is one such case. Of course, in cases where there is no reasonable direct or indirect evidence of what the person's subjective preference would be when he or she becomes incompetent, the objective test would have to suffice. For an interesting atteinpt to specify relatively precisely the risk/benefit ratio of hospitalization (in the context of determining the proper length of commitment), see Comment, Substantive Due Process Limits on the Duration of Civil Commitment for the Treatment of Mental IIIness, 16 HaRv. C.R.C.L. L. REv. 205, 226-39, 259-64 (1981). 
presented for special treatment of the mentally disordered and substantial overcommitment is inevitable. That Drs. Stone and Roth made no pretense of working out every detail is a source of little comfort because the problems outlined here cannot be remedied by definitional or procedural tinkering. In his proposal, Dr. Roth alludes to the general problem of the "dishonest" application of commitment criteria. ${ }^{160} \mathrm{Al}-$ though the Stone-Roth proposal, like most commitment proposals, aims to do good, it too would be "dishonestly" applied and many citizens would needlessly be deprived of their liberty. Moreover, the proposals do not and cannot reforn the conditions in state lospitals and raise their level of care. The Stone-Roth proposal may be better than most, but the mentally disordered, mental health professionals, and society would be better off if the system of involuntary hospitalization simply and completely ceased to exist.

\section{III}

\section{The Benefits of ABolition}

The benefits of abolition or severe limitation of involuntary commitment will be an increase in liberty, a reduction in the role confusion and onerous tasks of mental liealth professionals, the enhancement of treatment, and the freeing of wasted resources.

\section{A. The Extension of Liberty}

The primary benefit of abolition will be an increase in liberty in our society. People who are not demonstrably dangerous will not be preventively detainable, nor will the state be able to substitute its judgments for those of its citizens. Preventive detention is simply imsupportable, because it is a vast deprivation of liberty that is not outweighed by needs for public protection. The model of the criminal law is worthy of emulatimg; persons should not be incarcerated, no matter how dangerous they are, until they commit a proscribed act. ${ }^{161}$ Furthernore, as long as a person is capable of expressing a preference about hospitalization and treatment, the state should not be able to substitute its judgment for that preference. Nonprotesting persons could be liospitalized and treated until they indicated they no longer desired such services. But a commitment to liuman dignity and liberty requires that all persons be allowed to decide for themselves issues as

160. Roth, supra note 145 , at 1122. This refers to loose application of commitment criteria in order to achieve hospitalization. It does not mean that those who do so are malevolent; indeed, their motives are often therapeutic. Nevertheless, the result of dislonest application is the unlawful commitment of many citizens.

161. But $c f$. W. LAFAve \& A. ScotT, supra note 16 , at $423-27$ (the law of criminal attempts will ofteu allow the state to intervene before harm occurs). 
important as psychiatric hospitalization and treatment, even if the reasons that they give seem crazy and not hospitalizing and treating them seems inhumane. ${ }^{162}$ This mcompatibility betwcen liberty and humaneness is unfortunately fundamental; stringently limiting involuntary commitment can do no more than make the two goals imcrementally less incompatible.

Several counterarguments may be made to the position that liberty will be mcreased by abohtion. One response stems from the observation that some objecting patients are in fact ambivalent about their hospitalization. ${ }^{163}$ On the basis of this observation, one might argue that some of the protesters are not being wrongly committed because they "really" want to go into a hospital. Stated another way, the commitment system is simply helping large numbers of persons to obtain hospitalization without having to admit to themselves that they want it. Although ambivalence surely exists, this argument is entirely unpersuasive.

How can the relative strengths of the conflictimg desires be measured and compared? How do we know what a person "really" wants to do? There is no way at present to answer these questions. A sensible legal system must develop reasonable decision rules that use workable and reasonably objective criteria. The most workable and reasonable is to accept the overtly articulated desire of the person, even if other behavior gives some indication of ambivalence. Assessing unconscious motives is problematic at best; ${ }^{164}$ basing decisions on such motives is simply an invitation to subjective and widely discretionary dccisionmaking. In the criminal law, a person who intentionally shoots at another and misses will be guilty of attempted murder even though alienists of the unconscious may try to show that, because of unconscious conflict, the person did not "really" intend to kill. However, the assailant's intentional act must be determinative unless we are to make a mockery of notions of criminal responsibility and the relevance of mental state explanations to moral, practical, and legal judgments. ${ }^{165}$ And so it should be im the commitment system. If a person "really" wishes to enter the hospital, let that person sign in voluntarily. We can try to reduce ambivalence by offering efficacious community treatments. But if any person consciously protests, that decision must be respected although there is evidence of ambivalence. Liberty, dignity, and principled decisionmaking require this. ${ }^{166}$

162. Morse, supra note 23, at 627-39.

163. C. Warren, supra note 106 , at $89-94$.

164. Morse, Failed Explanations and Criminal Responsibility: Experts and The Unconscious (forthcoming in 68 VA. L. REv. - (1982)).

165. Moore, Responsibility and the Unconscious, 53 S. CAL. L. Rev. 1563, 1639-75 (1980).

166. There will be some model cases where the person objects to hospitalization but his or her 
Another possible counterargument is based upon cases of disordered persons that seem to cry out for intervention: the delusional person who seems on the verge of a violent outburst or who appears to be destroying the fabric of his or her family; the terribly disorganized person whose life is apparently in jeopardy because he or she seems unable to cope with minimal food, shelter, clothing, or medical needs; the person in the throes of a manic episode who appears to be jeopardizing a career or reputation; or, perhaps inost compellingly, the person on the verge of suicide who appears clearly to be making a mistake in judgment about his or her helplessness and the hopelessness of his or her life situation. Proponents of commitment point to such cases and claim that, in the name of decency and humanity, society inust intervene. ${ }^{167}$ It may be claimed that in such situations the disordered person lacks "effective" liberty, that the only freedoin one then lias is the freedoin to destroy one's life or to live in misery.

But the argument that freedom is illusory for some crazy persons because they lead lives of degradation and misery cannot be proven or quickly proves too much. A great number of persons who are not crazy lead lives of degradation and misery and could probably be helped by social rehabilitation measures, but we respect their right to liberty rather than deprive them of their freedo1n by forcing thein into rehabilitation programs in locked institutions. Distinguishing between the two, based on the presumption that the inentally disordered are "possessed" by their illnesses and thus cannot choose how to lead their lives, is unsatisfactory. As previously discussed, the behef that the mentally disordered are not autonomous is little inore than an intuitive hunch, especially in light of evidence that shows even the craziest person has substantial control over his behavior. ${ }^{168}$ More importantly, that person lias an malienable riglit to liberty that is indistinguishable from that of more "normal" citizens. ${ }^{169}$ Of course, useful voluntary services should be offered to crazy, disabled persons, and we sliould atteinpt to persuade needy citizens to make use of them. Moreover, as previously noted, nonprotesting persons may be treated. ${ }^{170}$ But if we do not override even the most horrendously irrational decisions of normal persons

behavior appears to be a clear cry for hospitalization. Such cases will be few, and even they will be open to other interpretations. Moreover, it bears repeating that we should not construct a system that will operate improperly most of the time simply to be able to deal with the few cases for which that system is theoretically appropriate.

167. Chodoff, supra note 58; see, e.g., Dickey, supra note 60, at 32-33.

168. See text accompanying notes 15-29 supra; see also Wear, supra note 15, at 293, 303-05.

169. Morse, supra note 23, at 653.

170. See text following note 161 supra. By a nonprotesting person, I mean a person so disabled that he or she is unable to respond coherently or to respond at all to an offer of services. In such cases, emergency services can of course be provided, but a guardianship should be sought to look after the person's more long term needs. When that person recovers sufficiently to express a 
that endanger their hives or the welfare of their families, ${ }^{171}$ we have no justification for authorizing a greater deprivation of liberty for those who are termed mentally disordered. To claim that we care about the "effective" liberty of crazy people but to be willing to ignore its lack in the lives of "normals" simply exposes the hypocrisy of the involuntary commitment system.

The solution to the appalling problems of the mentally disordered is not a system of involuntary mcarceration that is overutitized and insufficiently therapeutic. Hospitalization of the disordered simply evades the reahity of their problems. ${ }^{172}$ It is outrageous that our society has followed deinstitutionalization with the malevolent neglect of needy disordered persons. The fair comparison is not between hospitalization and neglect; it is between hospitalization and community treatment-a system in which society performs its moral obligations. The solution to those problems lies in the provision of resources $m$ the community to ensure decent food, clothing, shelter, and treatment services for those who need them. To the extent that severely disabled crazy people can realize their right to "effective" liberty, they can only do so in the community under conditions that minimize constraints on freedom. Thus, although the scandalous condition of many disordered persons im the community is undeniable, the conclusion sometimes drawn-that increased utilization of involuntary hospitalization is necessary-is both a breathtaking non sequitur and cynical. ${ }^{173}$

A final and admittedly problematic counterpoint to the liberty argument concerns the relationship of the involuntary commitment system to the criminal justice system. Both are deviance control systems that often deal with the same behavior. For instance, an assault, a

preference about hospitalization and treatment, however, that preference should be respected and the guardianship should terminate.

It may be objected that this system will not work because some persons might manage to pull themselves together for a brief moment and express a preference for treatment to cease, and then lapse back into incoherence. The system will be inefficient and useless in such cases. In these polar cases, this objection would be valid, but again, most cases are not polar and dificulties can be surmounted if a rule of reasonableness is apphed. Most patients will not move in and out of imcoherence so rapidly, and if they do, treatment clearly should not cease. On the other hand, the wish of a patient who is recompensating with reasonable stability should be respected. If the patient asks when coherent to be left alone even when imcoherent, this request should also be respected. Of course, the system will not be perfect, but it does strike a balance between liberty and paternalism that errs, properly I beheve, on the side of liberty.

171. Consider again the exaunple, discussed in the text accompanying notes 28-29 supra, of the heart attack victim who contimues to overeat, overwork, and smoke.

172. Cf. Gruenberg \& Archer, Abandonment of Responsibility for the Seriously Mentally III, 57 Milbank MemoRial Fund Q./HEAlth \& Society 485 (1979) (society evades responsibility for care of the mentally disordered no matter where provided). See generally Test \& Stein, supra note 137.

173. See Borus, supra note 142, at 342 ("It is to be loped that reinstitutionalization will not be the next "new" political remedy....."). 
petty theft, or vagrancy may be seen as a misdemeanor, a symptom of mental disorder, or both. Depending on a number of factors, a policeman may decide either to arrest the person or to take the person to a hospital. Many people beheve that if criminal conduct is a consequence of mental disorder and not too serious, it is unwise policy to use the criminal justice system to respond to the behavior. With soine cause, they see the criminal justice system as an mefficient and cruel institution in which to place persons who are not really responsible for their acts and who need treatmcnt, not pumshment. If involuntary commitment is abolished, the argument concludes, large numbers of crazy persons will be improperly forced into the criminal justice system. As a consequence, the supposed liberty benefits provided by abohition of involuntary commitment will be undermined and the mentally disordered will be subjected to cruel conditions.

The primary problein with this argument is that it entirely begs the question of criminal responsibility. It assumes that the miscreant could not have been responsible because he or she was mentally disordered. But, as argued at great length elsewhere, ${ }^{174}$ it is fair to hold nearly all persons, mcluding crazy persons, responsible for their behavior. If this is correct, then there is no reason not to use the criminal law to control criminal deviance. People can be both mad and bad. And to the extent they are bad, they deserve to be punished, especially if it appears possible that treating people as responsible encourages them to take responsibility for themselves. Further, the counterclaims, first, that the criminal sanction, mcluding jail terms, cannot deter disordered persons because their crime is a product of disorder and, second, that hospitalization will more effectively reduce criminal recidivism anong the mentally disordered, are simply unproven assertions.

The goal of providing treatment for inentally disordered persons who commit a crime should not preclude use of the criminal justice system. If treatment, such as drugs or psychotherapy, is required, it can be provided in jails; hospitals provide very little that is necessarily unique to them. Although it is unlikcly that jails will provide treatment services equal to those available in hospitals, it is equally unlikely that many petty, disordered criminals will spend much time in jail. In any event, the treatınent services available in jails are often inexcusably poor and should be vastly improved. ${ }^{175}$

To the extent that the criminalization problcm is created by puttimg mentally disordered persons in inhumane jails for minor crimes

174. Morse, The Twilight of Welfare Criminology: A Reply to Judge Bazelon, 49 S. CAL. L. REv. 1247, 1250-54 (1976); Morse, supra note 23, at 560-90.

175. U.S. General Accounting Office, Jail Inmates' Mental Health Care Neglected: State and Federal Attention Needed (1980). 
such as vagrancy, perhaps the solution is to abolish such crimes and to improve the jails, not to mamtain hospitals so that jail can be avoided by perpetrators of such arguably uimecessary crimes. Of course, vagrancy and like crimes may remain on the books, but reform in one area cannot always await reforms in other areas. To require thorough reform of a system before allowing reform of any one part is to prevent any reform at all.

If involuntary commitment is abolished, there may well be an imcrease im the processing of cases of relatively mild deviance through the criminal justice system and imcreased numbers of crazy persons may spend some time im unpleasant and often terrible jails. ${ }^{176}$ But, if crazy persons are almost always responsible for their behavior, and if incarceration in a jail is justified, there is no reason why they sliould not go to jail. This outcome is in fact more respectful of the dignity and autonomy of crazy persons than assuming that they are nonresponsible and must be "fixed." Jails and locked hospitals are both massive intrusions on hberty. The best response to the argument that jails are bad places, as they surely are for noncrazy and crazy minates alike, is to clean them up. Using unjustified hospitalization-merely another form of incarceration that offers little if any of the benefits it promises-to avoid jails is not a sensible solution to the problems of criminal justice; it merely allows us to avoid those problems.

In sum, abolition of involuntary commitment would be a positive contribution to the climate of freedom in our society. The promised workability and benefits of the involuntary commitment system are, for the most part, illusory; the actual harm likely to flow from its abolition is small. ${ }^{177}$ If involuntary commitment is abohshed, the nentally disordered will no longer be subject to special restraints on their right to physical hiberty, freedom of speech, freedoin of association, and other fundamental rights. Although involuntary commitment may prevent harm im a few cases, our society should be willing to allow some preventable harms in order to increase the liberty of its citizens.

\section{B. Benefits to Mental Health Professionals}

Mental health professionals would benefit enormously from the abolition of involuntary commitment. First, abolition would clearly reduce the role confusion and waste of resources engendered by professionals acting as both healers and agents of social control. Second, if the imvoluntary aspects of mental health practice were abolished, the

176. Dickey, supra note 60, at 30, 36; ENkI RESEARCH INSTITUTE, A STUDY OF CAL1FORNIA'S New Mental Health LAw (1969-1971) at 185-88 (1972).

177. Test \& Stein, supra note 142, at 409; Panel Report, 5 J. PsychiAT. \& L. 7, $22-25$ (1977). 
tensions, discomforts, and waste of resources created by legal regulation of the practice would be greatly reduced.

There would seem to be little reason for mental liealtl professionals to assume the role of agents of social control. If involuntary coinmitment and treatment were abolished, inental health professionals would still be faced with inore voluntary patients than they could treat adequately. It may reasonably be estimated that roughly five million persons in our society suffer froin severe inental disorders (soinewhat over two million of whom are chronically and severely disabled) and could benefit fronı treatınent. ${ }^{178}$ If all "pedigreed" mental lealtl professionals (psychiatrists, psychologists, psychiatric social workers, psychiatric nurses) were to ignore all other client populations and treat only severely disordered persons, there would still be far too few professionals to provide even nioderately good treatment to all the nienibers of that group. ${ }^{179}$ Furthermore, it is reasonable to assume tliat

178. It is virtually impossible to obtain precise figures on these questions. The five million figure is calculated on the basis of: (1) estimates that there are approximately two million schizophrenics in the U.S., Report of the Task Panel on the Nature and Scope of the Problems, in 2 Task Panel Reports Submitted to the President's Commission on Mental Health, app. at 19 (1978); (2) estimates that the prevalence rate for the clinical depression syndrome is $6.9 \%$ of the population and the prevalence rate for bipolar affective disorder is 0.3-1.2\%. Id. app. at 22-23. Assuming that this is a total prevalence of about $7.5 \%$ for affective disorders, then approximately 17 million Americans suffer from such disorders. I am then estimating, conservatively I beheve, that at any one time $10-20 \%$ of such persons are severely disordered. This adds approximately another two million persons to the estimate; (3) I am assuming that persons with severe mental health consequences of organic brani syndrome (unrelated to alcohol and drug use) and alcohol and drug use comprise at least one million inore people-a conservative estimate. Thus a total of five million is reached.

The figure in the text of somewhat over two million chronically, severely disordered persons is taken from Talbott, The National Plan for the Chronically Mentally Ill: A Programmatic Analysis, 32 Hosp. \& Comm. Psychiar. 699, 700 (1981). Talbott estimates that 2.4 million people are moderately to severely disabled and that 1.7 million are chronically severely disabled (of these, $4 \%$ are children). Talbott properly assumes that all these people need services. Id. It should be added that Talbott estimates that there are only three million people who are severely disordered, but $I$ beheve his figures are unduly conservative.

179. For example, there are approximately 33,000 psychiatrists and probably another 24,000 clinical psychologists in the country-a total of approximately 57,000 primary care givers. Brief Amicus Curiae for the American Psychiatric Association, supra note 91, at 3 (psychiatrists); Dorken \& Webb, Licensed Psychologists on Increase-1974-79, 36 AM. Psychol. 1419 (1981) (psychologists). If these professionals were to turu their full attention to treating only the severely ill and were to cease treating all other disordered persons or to perform any other roles im addition to treatment (e.g., teaching, research, supervising trainees, administration), each professional would have over fifty patients. Put another way, if there are three million severely disordered persons in our society (the most conservative estimate), each would receive less than one hour per week of attention from the most traimed professionals (calculated on the basis of a 50 hour work week). Moreover, if we assume, as do many psychiatrists, that specifically psychiatric treatment is necessary for the most disordered, then each patient would receive ouly about one-half hour of treatment per week from a psychiatrist. And, of course, these figures are obviously absurd and unrealistically optimistic because all psychiatrists and psychologists (and other professionals) will not behave as assumed hypothetically in this note, and our society will insist on mental health service for the far greater number of citizens who suffer from less severe mental disorders. 
within the group of severely disordered persons, the subgroup that would consent to efficacious and humane services is still larger than could reasonably be treated given current mental health resources. Therefore, one must ask why mental health professionals want to confine and treat some severely disordered persons involuntarily when there are insufficient professionals and resources to treat adequately those severely disordered persons who would want services. The question becomes even more difficult to answer when one considers that their role in the current commitment system as agents of social control is antithetical to their professional desires and training. ${ }^{180}$

A first answer often given is that there are dangerous people who need to be confined for the protection of others. Why, then, should we not turn this task over to the criminal justice system as Drs. Stone and Roth, for example, have suggested? Social control of truly dangerous people should be left to the institutions expert at dealing with such problems - the police and the criminal justice system. ${ }^{181}$

Another response is that some disordered persons are dangerous to themselves and would be abandoned to preventable suffering and degradation (and perhaps even death) if society did not intervene. This is perhaps true, but in the context of severely limited resources, time spent treating involuntary patients is time spent not treating patients who want services and who will face equally preventable harins. If only a limited amount of suffering, degradation, and other harins can be prevented, why not help those who want help? The maximum amount of care and prevention would still be offered and all the ancillary costs created by the imvoluntary system would be avoided.

Healing is a goal that is, and should be, distinct from social control. The former is benign and seeks to help needy individuals. The latter is punitive in effect and seeks to protect society at the individual's expense. The business of mental health professionals should be to give care, comfort, and treatment to disordered, disabled persons who seek their help. When mental health professionals are asked to decide who should be locked up or to ensure that those who are locked up remain incarcerated, they are asked to perforn functions for whicl they lack the training and the desire. They are trained to treat patients, not to house inmates. If treatnient services were fully voluntary, professionals could devote their full time to donig what they are trained for and de-

180. The noted forensic psychiatrist, Dr. Seymour Halleck of the University of North Carolina, has suggested that psychiatric residents and new psychiatrists should not be allowed to participate in the involuntary commitment process because it corrupts then. Remarks to the Audience at the 6th International Symposium on Law and Psychiatry, Charlottesville, Va., June 13, 1981. Dr. Halleck also suggested that at least some psychiatrists enjoy their power in the involuntary commitment system and would be loathe to give it up.

181. A. StONE, supra note 43, at 37, 192-94; Roth, supra note 145, at 1126. 
sire to do-caring for and treating suffering persons who want help. Moreover, they would no longer be forced into the onerous role of coercive control agents whose interests are at least in part opposed to those of their patients.

Abolition would also address the soinewhat justified complaints of mental health professionals about the legalization of their practices. Mental health professionals charge that legalization intrudes unduly on professional prerogatives and makes the provision of adequate mental health care almost impossible. ${ }^{182}$ Some critics of legalization fail to recognize three important points, lowever. First, legal reform was, in part, a response to documented medical and legal abuses; there is little reason to believe such abuses would not recur if the fetters of legalization were removed. Second, in our society, legal regulation of a system that leads to such an extensive deprivation of liberty is unavoidable. Legalization clearly intrudes on inental health practice, but it is absolutely necessary to protect the rights of patients who may be imcarcerated and treated involuntarily. Third and nosi important, proponents of involuntary hospitalization fail to recognize that if the imvoluntary aspects of inental health practice were abolished, most of the intrusive fetters of legalization also would be abolished. Court hearings and other legal second-guessings about decisions to hospitalize and treat a person are necessary only if these decisions are made agamst the will of the patient. If psychiatric services were voluntary, their regulation, like regulation of inost medical practice, could be left to internal professional review and suits for malpractice.

In addition to removing the shackles of legal regulation, abolition would also help remove mental health professionals from the role of courtrooin experts, a role ill-suited to their training and societal needs. ${ }^{183}$ Civil commitment hearings generally require expert testimony from mental health professionals, who are often given the de facto power to decide the ultimate legal issue of whether a person should be imvoluntarily incarcerated in a mental hospital. ${ }^{184}$ of course,

182. A. Stone, supra note 127 , at $29-31$, has provided an enormously amusing if somewhat inapt scenario describing this argument. In the scenario, lawyers are asked to imagine the impact on their practices of oversight and constant intrusion by psychiatric advocates. Dr. Stone recognizes, however, that unfettered inedical discretion led to abuses. A. STone, supra note 43, at 1.

183. Ennis \& Litwack, supra note 64, at 734-43; Morse, supra note 23, at 625. See generally J. ZISKIN, supra note 75.

184. See Cohen, The Function of the Attorney and the Commitment of the Mentally III, 44 TEX. L. Rev. 424, 428-30 (1966); Fein \& Miller, Legal Processes and Adjudication in Mental Incompetency Proceedings, 20 Soc. PROB. 57, 63 (1972); Scheff, Social Conditions for Rationality: How Urban and Rural Courts Deal with the Mentally Ill, AM. BEHAv. SCIENTIST, Mar. 1964, at 21; Stier \& Stoebe, supra note 78, at 1353; Wenger \& Fletcher, The Effect of Legal Counsel on Admissions to a State Mental Hospital: A Confrontation of Professions, $10 \mathrm{~J}$. OF Health \& Human Behavior 66 (1969); Wexler, The Administration of Psychiatric Justice: Theory and Practice in Arizona, 13 
such professionals are not legal, moral, or social experts and thus are being asked to decide questions beyond their competence.

Although the problem of professionals' testimony becoming dispositive can, to a large degree, be prevented by asking experts the right questions and by not allowing them to testify on ultimate legal issues, ${ }^{185}$ there would still be a significant imefficiency inherent in the system. Expert testimony and the examinations upon which it is based require the expenditure of much professional time that would be better spent providing therapeutic services. ${ }^{186}$ When a psychiatrist or psychologist from an understaffed state hospital must spend a morning im court, many hours of treatment expertise are wasted to the detriment of patients, with little consequent benefit to society or to the person involuntarily committed. Moreover, simce anything less than complete and competent expert testimony would fail to provide the factfinder with the information necessary for a full and fair hearing, this problein cannot be remedied by reducing the time spent by mental health professionals in commitment hearimgs.

Abohition of involuntary commitment would thus seem to be in the self-imterest of mental health professionals. Not only would they be able to avoid practicing in the shackles of the legal system, but they would be able to spend their time using their talents im the most productive way-helping patients who want to be helped.

\section{The Enhancement of Treatment}

As a matter of well-grounded speculation, it can be expected that treatment in general will be enhanced if it is offered voluntarily. This point seems to be generally recognized, as evidenced by the clear preference nationwide for voluntary services. ${ }^{187}$ If the treatimg professional is entirely the patient's agent and is not perceived also as an agent of the state, the therapeutic alliance and the ameliorative imfluence of the therapist's authority will surely be strengthened. If treatments are offered in a respectful and caring fashion and the benefits and costs are

ARIz. L. REv. I, 60 \& n.195 (1971). But see Hiday, Court Decisions in Civil Commitment: Independence or Deference?, 4 INT. J. L. \& Psychiat. I59 (I98I).

185. A complete argument concerning this proposition is presented in Morse, supra note 23, at 600-04; see also Washington v. United States, 390 F.2d 444, 454-57 (D.C. Cir. 1967) (insanity defense cases).

186. Shwed, Protecting the Rights of the Mentally III, 64 A.B.A.J. 564, 567 (1978); Slovenko, Criminal Justice Procedures in Civil Commitment, 24 WAYNE L. REv. 1, 35 (1977).

187. Lanterman-Petris-Short Act, CAL. WeLF. \& INST. CODE \& 5000 (West 1972 \& Supp. 1980); Wexler, Foreword: Mental Health Law and the Movement Toward Voluntary Treatment, 62 CALIF. L. REv. 671, 675-92 (1974); $c f$. Steinglass, Grantham \& Hertzman, Predicting Which $P a-$ tients Will Be Discharged Against Medical Advice: A Pilot Study, 137 AM. J. Psych1AT. 1385 (1980) (differences between patients and treatment staff as to nature of "therapeutic contract" is valid predictor of which patients will eventually be discharged against medical advice). 
explained clearly and patiently to the disordered person, one can expect much less resistance to treatment and the optimum chance for therapeutic gain. This type of behavior may take a lot of time, but it is nothing unore than the preferred, traditional, voluntary, contractual mode of treatment imitiation. Furthermore, as already discussed, instituting such a voluntary scheme would also result in a more efficient allocation of mental health resources, ${ }^{188}$ which in itself should lead to better overall inental health care.

\section{Cost Savings}

A final benefit of abolition will be the freeing of the resources now spent on umecessary hospitalization, custodial care, and the legal apparatus necessary to ensure the minimal fairness of the system. It has already been noted that custodial hospitalization is terribly expensive and wasteful and that most needed mental health treatment and services can be provided effectively and cheaply on an outpatient basis. ${ }^{189}$ If involuntary commitment were abolished, the funds formerly spent on the commitment system could be used to enhance community services so that they could reach a greater number of needy citizens at a higher level of quahity.

It inay be contended that demstitutionalization will not be cheaper if it is accomplished properly, given the substantial cost of community treatments and the increase in their utilization that might be expected. Mental health treatment is undeniably expensive, but per patient it is cheaper in the community than when involuntary hospitalization is employed. ${ }^{190}$ Furthermore, if increased utilization is the result of offering quality treatment in the community on a voluntary basis, that should be seen as a factor in its favor rather than as a reason for decreasing community services and increasing involuntary hospitalization.

Involuntary commitment provides few people with few benefits at great cost. Abolition would niake possible the treatment, under conditions of freedoin, of greater numbers with greater benefit.

\section{CONCLUSION \\ "LEGALIZATION" AND THE FUTURE OF INVOLUNTARY COMMITMENT}

For the past two decades, lawyers, some mental health professionals and others interested in liberty and huniane treatment for mentally

188. See text accompanying notes 178-86 supra.

189. Chambers, supra note 137, at 1121-37; sources cited at notes 137 \& 142 supra. But see Letter from M. Sills to the Editor, 38 ARCh. Gen. Psychiat. 599 (1981).

190. E.g., Murphy \& Datel, A Cost-Benefit Analysis of Community Versus Institutional Living, 27 Hosp. \& COMM. PSYCHIAT. 105 (1976). 
disordered persons have litigated and lobbied ceaselessly to restrict the criteria for imvoluntary commitment, to promote demstitutionalization and other alternatives to imvoluntary incarceration, to mcrease the procedural protections accorded to those in danger of commitment, and to expand the civil hiberties of patients and ex-patients. The result has been a cascade of litigation and legislation that has "legalized" the commitment process and, consequently, has done much to further the described goals of the patients' rights advocates. ${ }^{191}$ That this legalization has done some good and that patients should have rights (at least in theory) nearly all will admit. ${ }^{192}$ But, it is countered, the process has nonetheless gone too far. ${ }^{193}$

The argument that legalization has gone too far or has caused more problems than it has solved is entirely incorrect. Before the interventions of the patients' advocates, patients had almost no rights in practice and most commitments involved hittle more than warehousing under often brutal conditions. One must constantly remember that the right to treatment and right to rehabilitation suits that exposed the utterly shocking and inhumane conditions in state hospitals in various states ${ }^{194}$ were products of the 1970 's, not the distant past. There is hittle if any indication that, in general, patients were obtaining rights or decent care and treatment prior to the legalization movement. This is not to claim that legalization has been a panacea; indeed, vast problems remam. ${ }^{195}$ Nor can it be deined that undertrained or overzealous advocates may liave overstepped their bounds and disrupted programs in some instances. ${ }^{196}$ Patients are still overcommitted, however, and the

191. See Schwitzgebel, supra note 5, at 53.

192. See L. Kahle \& B. Sales, Due Process of Law and the Attitudes of Professionals Toward Involumiary Civil Commilment, in New DiREctions in PsYCHOLOGICAL ReseARCH 265 (P. Lipsitt \& B. Sales eds. 1979).

193. Brakel, Legal Aid in Mental Hospitals, 1981 AM. B. Foundation Research J. 23.

194. E.g., Halderman v. Pennhurst State School \& Hosp., 446 F. Supp. 1295 (E.D. Pa. 1977) 451 F. Supp. 233 (E.D. Pa. 1978), modifed, 612 F.2d 84 (3d Cir. 1979), rev'd and remanded, 101 S. Ct. 153I (1981); New York State Ass'n for Retarded Children, Inc. v. Rockefeller, 357 F. Supp. 752 (E.D.N.Y. 1973); Wyatt v. Stickney, 325 F. Supp. 781 (M.D. Ala. 1971), 334 F. Supp. 1341 (M.D. Ala. 1971), enforced by 344 F. Supp. 373 and 344 F. Supp. 387 (M.D. Ala. 1972), affd in part, rev'd and remanded in part on other grounds sub nom. Wyatt v. Aderholt, 503 F.2d 1305 (5th Cir. 1974).

195. See Dickey, supra note 60, at 22-40; Stier \& Stoebe, supra note 78, at 1284-435; sources cited in notes 132 \& 143 supra.

196. Brakel, supra note 193, at 74-77. It should be pointed out, however, that some disruption is the inevitable product of a system that exists in tension between hiberty and paternalism and that allows advocates to help patients. Disruption could be mimimized, however, by various procedural innovations. For instance, if the conditions of confinement, imcluding the provision of involuntary treatment, were adjudicated and ordered at the initial commitment hearing, conflict within the hospital might be lessened and would arise mainly if there was a substantial deterioration in the patient's condition or if the hospital failed to provide the requisite rights and care to the patient. 
conditions of confinement and the treatment they receive still fall far short of what is acceptable.

Legalization has not gone too far-it has not gone far enough. Society and the mental health professions have not been willing on their own initiative to provide sufficient services to needy, mentally disordered citizens. Legalization's continued intrusion on mental health care would be unnecessary if society cared for its chronically disabled citizens and if the mental health professions were willing to put their houses in order. Since neither of these conditions obtams, it is the duty of legalization proponents to seek to limit current involuntary commitment, to make it more humane, and ultiniately, one hopes, to contribute to its abolition.

Many will argue in response to the argument in favor of abolition (or restriction) that neental disorder and the social and familial problems it causes cannot be abolished. Moreover, they will predict that disordered persons will live in the community, as many do now, in a state of inisery and degradation. The first point cannot be gainsaid: mental disorder-whether it is conceptualized as disease or deviant conduct or whatever-and its consequences will continue. It is also true that the conditions under which many disordered persons now live in the community are repulsive and a moral disgrace to our society. These problems require attention. However, maintaining involuntary hospitalization is not the answer. The systent, as now constituted, does not alleviate substantially the ills of the disordered; rather, it only removes disordered persons and their problems from the consciousness and conscience of our society at an enormous cost in liberty. If there is a solution, however partial, it lies in providing the resources to ensure that decent food, shelter, clothing, and treatment are provided in the community in the least restrictive manner to those who need them.

The legalization movement is forcing society and the mental health professions to come to terms with what it is willing to do for and to its most disordered citizens. Do we mean to treat and cure people, or do we mean to cast them out and warehouse them? The movement has been successful because it has exposed the unfulfilled promises and the cant of the involuntary commitment systen. However reasonable an involuntary commitment system may seem in theory, past experience demonstrates that the system does not and cannot work.

Despite all this, the argunents in favor of involuntary commitment retam a seductive appeal that will probably prevent its abolition in the near future. Much of this appeal is predicated on a vision of mental health care in state hospitals that can only be described as mythical. Relatively pleasant hospitals are envisioned, with reasonably sufficient and competent staff who form caring relationships with most 
patients and who deliver quality treatments offering patients a reasonable possibility of cure. When a court or legislature succumbs to this vision, setbacks to legalization can occur. But to succumb to this vision is to ignore the harsh reality of commitment. If society never faces the reality, there will be cycles of greater and lesser civil rights for patients, but imvoluntary commitment and its consequent substandard care for the disordered will remaim. ${ }^{197}$

A false vision of the quality of care provided by involuntary commitment is not all that may thwart the legalization process. As legalization continues, society may become unwilling to pay tlee price in terms of caring and tolerance. Moreover, the material outlays necessary for proper treatment have not been, and probably will not be, fortlicoming. Persons who are concerned with treating disordered persons witl dignity and humanity must combat these problems and should strive to abolish, or at least severely restrict, involuntary commitment and to encourage the provision of adequate care in the community.

If care and treatment services are voluntary and reasonably provided to disordered persons and if social control is left primarily to the criminal justice system, our society, the nientally disordered, and even the mental health professions will be benefitted. Hospitals will still exist: some people will want treatnient there and perhaps some can best -or only-be treated in such an enviroument. A vast number of citizens, lowever, will for the first time be able to obtain needed services in an atmosphere of dignity and liberty. Professionals will be freed to devote their full time to the tasks of diagnosis and treatment for which they are truly tranied. There will be nuore than enough work, prestige, and power for mental health professionals who treat only willmg patients. Of course, if involuntary incarceration im a hospital is not available, disordered citizens nuay, on occasion, seriously endanger theinselves or others; no public policy, no matter how beneficial, is entirely cost free. Nonetheless, if the social climate of liberty is increased and if neentally disordered persons are finally treated as dignified and autononious human beimgs, then abolition of the involuntary commitnent systen is well worth any costs that are likely to result. 